\title{
Clinical-grade cryopreserved doxorubicin- loaded platelets: role of cancer cells and platelet extracellular vesicles activation loop
}

Yu-Wen Wu ${ }^{1} \mathbb{D}$, Cheng-Chain Huang ${ }^{2}$, Chun Austin Changou ${ }^{2,3}$, Long-Sheng Lu ${ }^{1,4,5,6,7} \mathbb{D}$, Hadi Goubran ${ }^{8}$ and Thierry Burnouf ${ }^{1,4,7^{*}}$ (D)

\begin{abstract}
Background: Human platelets (PLT) and PLT-extracellular vesicles (PEV) released upon thrombin activation express receptors that interact with tumour cells and, thus, can serve as a delivery platform of anti-cancer agents. Drugloaded nanoparticles coated with PLT membranes were demonstrated to have improved targeting efficiency to tumours, but remain impractical for clinical translation. PLT and PEV targeted drug delivery vehicles should facilitate clinical developments if clinical-grade procedures can be developed.

Methods: PLT from therapeutic-grade PLT concentrate (PC; N > 50) were loaded with doxorubicin (DOX) and stored at $-80^{\circ} \mathrm{C}$ (DOX-loaded PLT) with 6\% dimethyl sulfoxide (cryopreserved DOX-loaded PLT). Surface markers and function of cryopreserved DOX-loaded PLT was confirmed by Western blot and thromboelastography, respectively. The morphology of fresh and cryopreserved naïve and DOX-loaded PLT was observed by scanning electron microscopy. The content of tissue factor-expressing cancer-derived extracellular vesicles (TF-EV) present in conditioned medium (CM) of breast cancer cells cultures was measured. The drug release by fresh and cryopreserved DOX-loaded PLT triggered by various $\mathrm{pH}$ and $\mathrm{CM}$ was determined by high performance liquid chromatography. The thrombin activated PEV was analyzed by nanoparticle tracking analysis. The cellular uptake of DOX from PLT was observed by deconvolution microscopy. The cytotoxicities of DOX-loaded PLT, cryopreserved DOX-loaded PLT, DOX and liposomal DOX on breast, lung and colon cancer cells were analyzed by CCK-8 assay.

(Continued on next page)
\end{abstract}

\footnotetext{
* Correspondence: thburnouf@gmail.com

${ }^{1}$ Graduate Institute of Biomedical Materials and Tissue Engineering, College of Biomedical Engineering, Taipei Medical University, 250 Wu-Xing Street, Taipei 11031, Taiwan

${ }^{4}$ International PhD Program in Biomedical Engineering, College of Biomedical Engineering, Taipei Medical University, Taipei, Taiwan

Full list of author information is available at the end of the article
}

C C The Author(s). 2020 Open Access This article is licensed under a Creative Commons Attribution 4.0 International License, which permits use, sharing, adaptation, distribution and reproduction in any medium or format, as long as you give appropriate credit to the original author(s) and the source, provide a link to the Creative Commons licence, and indicate if changes were made. The images or other third party material in this article are included in the article's Creative Commons. licence, unless indicated otherwise in a credit line to the material. If material is not included in the article's Creative Commons licence and your intended use is not permitted by statutory regulation or exceeds the permitted use, you will need to obtain permission directly from the copyright holder. To view a copy of this licence, visit http://creativecommons.org/licenses/by/4.0/ The Creative Commons Public Domain Dedication waiver (http://creativecommons.org/publicdomain/zero/1.0/) applies to the data made available in this article, unless otherwise stated in a credit line to the data. 


\begin{abstract}
(Continued from previous page)
Results: $15 \sim 36 \times 10^{6}$ molecules of DOX could be loaded in each PLT within 3 to 9 days after collection. The characterization and bioreactivity of cryopreserved DOX-loaded PLT were preserved, as evidenced by (a) microscopic observations, (b) preservation of important PLT membrane markers CD41, CD61, protease activated receptor-1, (c) functional activity, (d) reactivity to TF-EV, and (e) efficient generation of PEV upon thrombin activation. The transfer of DOX from cryopreserved PLT to cancer cells was achieved within $90 \mathrm{~min}$, and stimulated by TF-EV and low pH. The cryopreserved DOX-loaded PLT formulation was 7 23-times more toxic to three cancer cells than liposomal DOX.
\end{abstract}

Conclusions: Cryopreserved DOX-loaded PLT can be prepared under clinically compliant conditions preserving the membrane functionality for anti-cancer therapy. These findings open perspectives for translational applications of PLT-based drug delivery systems.

Keywords: Cryopreserved platelet, Tissue factor, Cancer, Doxorubicin, Platelet extracellular vesicles, Drug delivery

\section{Background}

Human platelets (PLT) are abundant anucleated blood cells that are instrumental in hemostasis and tissue repair mechanisms $[1,2]$. However, there is an increasing recognition of the instrumental contribution of PLT to cancer progression. PLT enhances tumour growth by the release of growth factors, conceal circulating tumour cells from immune defense mechanisms, and prime metastasis [3-7]. In the tumour microenvironment, a detrimental PLTcancer cell activation loop is ignited, orchestrated by several functional PLT membrane receptors capable of targeting and interacting with cancer cell surface markers $[8$, 9]. The bioreactivity of PLT membranes to cancer cells culminate into PLT activation and "tumour cell-induced PLT aggregation" (TCIPA) [10, 11], which is triggered by tumour's tissue factor (TF). Further, cancer cell-derived extracellular vesicles expressing tissue factor (TF-EV), released in the tumour microenvironment, could induce PLT activation [12]. Activation also leads to alteration of the PLT membrane structure, exposure of procoagulant phosphatidylserine, generation of PLT-derived extracellular vesicles (PEV), conversion of prothrombin into active thrombin, resulting in the hypercoagulable state typically observed in cancer patients [13-15]. Reciprocally, PLT activated in the tumour microenvironment release growth factors and chemokines, either as free molecules or as entities entrapped in PEV, which favor tumour growth, angiogenesis, and metastasis [16-18]. The "vicious" pathogenic attraction existing between tumour cells and PLT membranes has recently stimulated the engineering of targeted PLT membrane-inspired nanocarriers aiming at delivering anti-cancer agents, following a so-called "Trojan Horse" strategy. In this approach, the PLT membrane machinery serves as a camouflage against the phagocytic system and is used to design smart drug delivery systems (DDS) with enhanced targeting ability to tumour cells [19-24]. This PLT mimicry strategy was indeed found in animal models to lower the uptake of synthetic nanoparticles by macrophages and to avoid nanoparticle-induced complement activation, and was also demonstrated to improve the targeting of nanoformulations to tumours [20, 22, 25-27]. For instance, doxorubicin (DOX)-loaded liposomes (liposomal DOX) functionalized by a few PLT membrane receptors, such as glycoprotein IIb-IIIa (GPIIb-IIIa), P-selectin, and GPIa-IIa, demonstrated enhanced targeting and binding capacity for highly metastatic breast cancer cells in both in vitro and in vivo models [26]. Functionalization with whole PLT membranes also improved the ability of nanocarriers to target diseased tissues [27]. Drugloaded nanoparticle/nanogel preparations coated with whole PLT membranes exerted potent toxicity against tumour cells and lowered the risk of metastasis in animal models $[20,28,29]$. Those studies are crucial proof-ofconcept and learning tools in understanding the capacity of the bioreactive PLT membrane machinery to target cancer cells. However, isolating PLT membranes and achieving nanoparticle coatings are highly challenging at production scale, since designing clinically compliant isolation and purification procedures of PLT membranes is difficult [24, 30]. In addition, PLT membrane isolation procedures may induce protein denaturation that may affect the targeting capacity and trigger immunogenicity [31]. Furthermore, PLT membrane-coated nanocarriers do not have the full biochemical cross-talk ability inherently exhibited by PLT themselves and remain biologically inert to biochemical signals present in the tumour microenvironment. We believe that, to overcome these drawbacks, using PLT themselves as drug carriers is currently the most realistic and rational approach for clinical translation [30]. We herein developed a process to prepare a stable PLT formulation that can be manufactured from therapeuticgrade autologous or allogeneic PLT concentrate (PC). The isolated PLT were loaded with DOX suspended in a licensed PLT additive solution (PAS) [32] to form fresh DOX-loaded PLT, and stored frozen at $-80^{\circ} \mathrm{C}$ using a $6 \%$ dimethyl sulfoxide (DMSO)-based formulation [33-37] (cryopreserved DOX-loaded PLT). Importantly, the capacity to store DOX-loaded PLT provides a logistically 
convenient and clinically compliant procedure that can benefit from the existing expertise in blood collection and transfusion medicine. We also demonstrate that the loading process of DOX and the freezing for long-term storage and ease of treatment does not affect (a) PLT function, in particular the membrane integrity or reactivity to tumour cell-derived TF and thrombin, (b) the capacity to generate PEV, and (c) the targeting and transfer of DOX to cancer cells. Our study unveils the unique and superior ability of cryopreserved intact PLT to serve as a "Trojan Horse" bioreactive delivery carrier of cancer drugs, through generation of potent PEV and enhanced release at low $\mathrm{pH}$ and in the presence of cancer cell-derived TF-EVs.

\section{Materials and methods \\ Therapeutic-grade PC collection}

The Institutional Review Board of Taipei Medical University approved this study (TMU-JIRB no.: 201502019). Over 50 clinical-grade PC, collected in 100\% plasma, were obtained from the Taipei Blood Center (Taiwan Blood Services Foundation, Guandu, Taiwan). PC was obtained from volunteer healthy donors. Apheresis PC was prepared using the licensed Haemonetics MCS + cell separator (Haemonetics Corp., Braintree, MA, USA) and whole blood-derived PC by the "platelet-rich-plasma" method. PC was anti-coagulated using a licensed citrate phosphate dextrose solution. All donations were tested and found to be non-reactive against mandatory viral markers, following local and international regulations. The PC was delivered within 3 days after collection to our laboratory where they were kept at $22 \pm 2{ }^{\circ} \mathrm{C}$ on a platelet agitator and processed on the same day or within 9 days of collection. PC was centrifuged at 1500 $\mathrm{xg}$ for $10 \mathrm{~min}$ to separate PLT and plasma. Plasma was also collected after additional centrifugation at $3000 \mathrm{xg}$ for $10 \mathrm{~min}$ twice to remove residual PLT. PLT and plasma were analyzed by ABC Vet (ABX Diagnostics, Montpellier, France) to determine the blood cell count.

\section{Preparation of fresh and cryopreserved DOX-loaded PLT}

PC was centrifuged at $1500 \mathrm{xg}$ for $10 \mathrm{~min}$ at $23 \pm 1{ }^{\circ} \mathrm{C}$ to pelletize PLT. PLT was then gently resuspended in a solution of $100 \mu \mathrm{M}$ DOX hydrochloride (LC Laboratories, Woburn, MA, USA) solubilized in PAS. The preparation was incubated gently on a suspension mixer (SM-3000; Yihder, Taipei, Taiwan) at $30 \pm 5 \mathrm{rpm}$ for $1 \mathrm{~h}$ at $37 \pm 1{ }^{\circ} \mathrm{C}$. Excess DOX was removed by centrifugation at $1500 \mathrm{xg}$ for $10 \mathrm{~min}$ at $23 \pm 1{ }^{\circ} \mathrm{C}$. The pellets were gently resuspended in PAS to generate fresh DOXloaded PLT or resuspended with 6\% DMSO (Sigma-Aldrich, ST. Louis, MO, USA) to prepare cryopreserved DOX-loaded PLT formation.

\section{Characterization of fresh and cryopreserved DOX-loaded PLT}

The concentration of DOX loaded in PLT isolated from PC stored from 3 to 9 days after collection was quantified. Preparation of DOX-loaded PLT is described above. $1 \mathrm{~mL}$ of DOX-loaded PLT pellets (ca. $1 \times 10^{9} \mathrm{PLT}$ ) were lysed with $5 \%$ sodium dodecylsulfate (SDS; Sigma-Aldrich) and the concentration of loaded DOX in the PLT was determined by fluorospectrometer $(470 / 585 \mathrm{~nm})$.

\section{Deconvolution fluorescence microscopy of DOX-loaded PLT}

Loading of DOX in PLT was visualized by immunofluorescence staining and observed by deconvolution microscopy. Degreased coverslips were coated with $200 \mu \mathrm{L}$ of 10 $\mathrm{mg} / \mathrm{ml}$ fibrinogen (Sigma-Aldrich) in saline at $22 \pm 2{ }^{\circ} \mathrm{C}$ for $30 \mathrm{~min}$ [38]. $2 \times 10^{8}$ DOX-loaded PLT were loaded onto the coverslip at $22 \pm 2{ }^{\circ} \mathrm{C}$ for $30 \mathrm{~min}$ and fixed with 2 $\mathrm{mL} 4 \%$ paraformaldehyde for $10 \mathrm{~min}$ followed by blocking with $200 \mu \mathrm{L} 2 \%$ bovine serum albumin (BSA; SigmaAldrich) in phosphate-buffered saline (PBS; Hyclone, Logan, UT, USA). CD41a PLT surface markers were stained with $200 \mu \mathrm{L}$ of mouse anti-human CD41a-APC (BD Bioscience, San Jose, CA, USA) at a 1:20 dilution in $2 \%$ BSA for $1 \mathrm{~h}$. The coverslips were mounted onto microscopic slides with $10 \mu \mathrm{L}$ Everbrite mounting medium with DAPI (Biotium, Hayward, CA, USA) and visualized by DeltaVision Personal Deconvolution Microscopy (GE Healthcare, Marlborough, MA, USA). Three digital (3D) images were generated by Volocity 6.3 software (PerkinElmer, Waltham, MA, USA).

\section{PLT morphology observed by scanning electron microscopy (SEM)}

To prove that freezing and drug loading did not affect the activation capacity, the morphology of PLT was observed by SEM (SU3500; Hitachi, Tokyo, Japan), using coverslips were coated with $10 \mathrm{mg} / \mathrm{mL}$ of fibrinogen (Sigma-Aldrich). Fresh and cryopreserved PLT and DOX-loaded PLT were loaded on the coverslips, and compared visually to DOX-loaded PLT loaded on the coverslip and activated with $0.1 \mathrm{U} / \mathrm{mL}$ thrombin (SigmaAldrich; $\left.37 \pm 1{ }^{\circ} \mathrm{C}, 30 \mathrm{~min}\right)$. Samples were fixed with $2 \%$ paraformaldehyde (Fluka, Buchs, Switzerland) and 2.5\% glutaraldehyde (Sigma-Aldrich) in $0.2 \mathrm{M}$ cacodylate (Sigma-Aldrich) for $30 \mathrm{~min}$, dehydrated using 70 100\% ethanol gradient solutions, and gold-coated.

\section{Western blot analysis of PLT membrane receptors}

Protein concentrations of PLT samples were determined by a Bradford protein assay kit (Thermo-Fisher Scientific, Waltham, MA, USA). $10 \mu \mathrm{g}$ of protein of each samples were mixed with $4 \mathrm{x}$ sample buffer and heated at $70{ }^{\circ} \mathrm{C}$ for $10 \mathrm{~min}$ before separation by SDS- 
polyacrylamide gel electrophoresis using a 4 12\% gradient gel. Proteins were transferred to polyvinylidene difluoride (Pall Corp., Port Washington, NY, USA) membranes, and blocked using 5\% skim milk. Membranes were incubated with antibodies against PLT glycoprotein IIb (CD41; Abcam, Cambridge, MA, USA), PLT glycoprotein IIIa (CD61; Abcam), protease activated receptor-1 (PAR1, R\&D Systems, Minneapolis, MN, USA), and glyceraldehyde 3-phosphate dehydrogenase (GAPDH) as the loading control (Novus Biologicals, Littleton, CO, USA). Horseradish peroxidase-conjugated antibodies (Jackson ImmunoResearch Laboratories, West Grove, PA, USA) were used as a secondary antibody. The detailed information of the antibodies used is in Table S2. Detection was done by enhanced chemiluminescence (ECL) (GE Healthcare). Bands were analyzed on a BioSpectrum 810 Imaging System (Analytik Jena, Jena, Germany).

\section{PLT function test}

The PLT function was assessed by thromboelastometry (TEG 5000 Thrombelastograph Hemostasis Analyzer System, Haemonetics). Samples were diluted with plasma to a content of $4 \times 10^{8} \mathrm{PLT} / \mathrm{mL}$, and mixed with $40 \mu \mathrm{L}$ kaolin, after which $330 \mu \mathrm{L}$ was placed in a cup with $30 \mu \mathrm{L}$ of $0.2 \mathrm{M}$ calcium chloride $\left(\mathrm{CaCl}_{2}\right.$; SigmaAldrich) for the thromboelastography analysis [39]. Platelet-poor plasma was used as a negative control. The following tracing parameters were evaluated: the reaction time $(\mathrm{R})$ to initial fibrin generation and the maximum amplitude (MA) to assess the maximum strength of clot formation, as described by the supplier.

\section{In vitro drug release profile Impact of $\mathrm{pH}$}

The in vitro release of DOX from loaded PLT was determined in PAS at pH 7.4 (control) and in PBS at pH 7.4, 6.5 , or 5.5. DOX-loaded PLT $\left(4 \times 10^{8}\right.$ PLT $)$ were suspended in $0.4 \mathrm{~mL}$ of a test solution, transferred into 1.5 $\mathrm{mL}$ Eppendorf tubes, and placed on a shaker (TS-500, Yihder Co.) at $50 \mathrm{rpm}$ and $22 \pm 2{ }^{\circ} \mathrm{C}$. Samples were taken at the start and after $6,12,24,48$, and $72 \mathrm{~h}$ of incubation. The suspension was centrifuged at the given time points in order to determine the residual amount of DOX still present in PLT. The pellet was lysed with 5\% SDS and diluted 5 -fold by $40 \%$ acetonitrile. The concentration of DOX was quantified by high performance liquid chromatography (HPLC; Hitachi) equipped with an Symmetry C18 column $(4.6 \times 150 \mathrm{~mm}, 3.5 \mu \mathrm{m}$ analytical column; Waters, Milford, MA, USA) maintained at $22 \pm$ $2{ }^{\circ} \mathrm{C}$. Chromatography was run at $1 \mathrm{~mL} / \mathrm{min}$ in $40 \%$ acetonitrile at pH 2.9 (citric acid monohydrate, SigmaAldrich) using a 470/585-nm fluorescence detector [40]. The calibration standards of DOX was prepared in $40 \%$ acetonitrile at concentration of 50, 100, 200, 500, 2000, $4000,6000 \mathrm{ng} / \mathrm{mL}$. The release profile of DOX from fresh or cryopreserved PLT was calculated according to the formula:

$$
\begin{aligned}
& \text { Cumulative DOX release }(\%) \\
& \quad=\left[1-\left(\frac{\text { Amount of DOX in PLT at time point }}{\text { Initial amount of DOX in PLT }}\right)\right] \times 100 \%
\end{aligned}
$$

\section{Impact of conditioned medium cultured with breast cancer cells}

In vitro release of DOX was measured when DOXloaded PLT was incubated in the supernatant of MDAMB-231 cell conditioned medium (CM) to mimic components of the tumour microenvironment. The release kinetics was compared to that determined when incubation was done in control medium (Dulbecco's modified Eagle medium; DMEM). Loaded PLT was suspended in culture medium and mixed on a shaker at $50 \mathrm{rpm}$ and $37^{\circ} \mathrm{C}$. At each pre-determined time points $(0,6,12,24$, 48 and $72 \mathrm{~h}$ ), the mixture was centrifuged (1500 $\mathrm{xg}$ for $10 \mathrm{~min}$ at $23 \pm 1^{\circ} \mathrm{C}$ ), and the supernatant was separated from the pellet. The concentration of DOX was determined by HPLC (Hitachi) and the formula of kinetic release of DOX was calculated as described above.

\section{Cell experiments}

MCF-7 (BCRC-60436; Bioresource Collection and Research Center, Hsin-Chu, Taiwan) and MDA-MB-231 (BCRC-60425) human breast cancer cells were grown in DMEM (Hyclone) supplemented with 10\% fetal bovine serum (FBS, Hyclone). The A549 (BCRC-960402) human lung cancer cell line was maintained in F12K medium (Gibco, Grand Island, NY, USA) supplemented with 10\% FBS. The HCT 116 (ATCC-CCL-227) human colon cancer cell line was preserved in McCoy's 5a modified medium (Gibco) supplemented with 10\% FBS. All cells were incubated at $37^{\circ} \mathrm{C}$ in a $5 \% \mathrm{CO}_{2}$ atmosphere.

\section{Cellular uptake of DOX-loaded PLT}

Microscopic observations and time-lapse of transfer to cancer cell nuclei was performed as follows. $10^{5} \mathrm{MCF}-7$ cells/well were seeded on coverslips in six-well plates and maintained at $37^{\circ} \mathrm{C}$ overnight. Approximately $2 \times$ $10^{8}$ DOX-loaded PLT were added, and the mixture was maintained at $37^{\circ} \mathrm{C}$ for $3 \mathrm{~h}$, then fixed using $4 \%$ paraformaldehyde (Fluka) for $10 \mathrm{~min}$ at $22 \pm 2{ }^{\circ} \mathrm{C}$, and washed with PBS (Hyclone) three times. Fixed cells were permeabilized using $0.1 \%$ Triton X-100 (Merck Millipore, Darmstadt, Germany) for $4 \mathrm{~min}$ at $22 \pm 2{ }^{\circ} \mathrm{C}$ and blocked with $1 \%$ BSA at $24 \pm 2{ }^{\circ} \mathrm{C}$ for $30 \mathrm{~min}$. Cells were then incubated with phalloidin Alexa-Fluor 647 (Life Technologies, Eugene, OR, USA) at a 1:40 dilution in 1\% BSA 
for $1 \mathrm{~h}$ to stain F-actin. Nuclei were stained by Mounting Medium with DAPI (Biotium). Cells were visualized by three-dimensional (3D) images by deconvolution fluorescence microscopy and analyzed by Volocity software (PerkinElmer). Further, DOX transfer from PLT to cells was observed for $90 \mathrm{~min}$ in real time (Figure S1). Briefly, $10^{5}$ MCF-7 cells were seeded on coverslips in glassbottom dishes and maintained at $37 \pm 1^{\circ} \mathrm{C}$ overnight. $2 \times 10^{8}$ DOX-loaded PLT were added to the dish, and then images were taken by deconvolution fluorescence microscopy over time, and a movie was generated with Volocity software (PerkinElmer).

\section{TF activity of conditioned medium cultured with breast cancer cells}

MDA-MB-231 cells $\left(5 \times 10^{6}\right)$ were seeded in a T-75 flask and grown for $24 \mathrm{~h}$ in DMEM (Hyclone) supplemented with $0.2 \mu \mathrm{m}$-filtered 10\% FBS (Hyclone). The medium was then replaced with $10 \mathrm{~mL}$ of complete culture medium, and cells were cultured for an additional $48 \mathrm{~h}$. Cell culture supernatants were centrifuged at $300 \mathrm{xg}$ to remove cells, then $3000 \mathrm{xg}$ for $10 \mathrm{~min}$ at $23 \pm 1{ }^{\circ} \mathrm{C}$ to remove cell debris. Supernatants of cancer cells (CM) and culture medium (DMEM) control were collected and frozen at $-80^{\circ} \mathrm{C}$ until the in vitro drug release test and MP-TF activity assay. The presence of TF-EV in the medium was determined by a functional Zymuphen MPTF capture assay (Hyphen BioMed, Neuville sur Oise, France) that measures the procoagulant activity of EV expressing TF. The endpoint absorbance was measured at $405 \mathrm{~nm}$ using a microplate reader (TECAN Trading AG, Mannedorf, Switzerland).

\section{TF activity and thrombin generation assay in the conditioned medium of MDA-MB-231 cells incubated with cryopreserved PLT}

$1 \times 10^{6}$ MDA-MB-231 cells were pelletized by centrifugation at $200 \mathrm{xg}$ at $23 \pm 1{ }^{\circ} \mathrm{C}$. Cell pellets were resuspended with $1 \mathrm{~mL}$ of plasma or with $3 \times 10^{9}$ cryopreserved PLT in plasma. In addition, plasma or $3 \times 10^{9}$ cryopreserved PLT in plasma were used as controls. All samples were incubated at $37^{\circ} \mathrm{C}$ for $1 \mathrm{~h}$ with stirring at $70 \mathrm{rpm}$ on a shaker (Yihder). Intact cells were removed by centrifugation at $300 \mathrm{xg}$ for $10 \mathrm{~min}$ followed by 3000 $\mathrm{xg}$ for $10 \mathrm{~min}$ to remove cell debris and PLT. The supernatant of each sample was collected to assess TF activity associated with EV ("MP-TF activity" assay) leading to thrombin generation. The generation of thrombin was measured by a fluorogenic substrate induced by TF and negatively charged phospholipid-containing EV. For the thrombin generation assay (Technoclone, Vienna, Austria), samples were incubated with a low concentration of phospholipid micelles containing recombinant human TF following manufacturer's instructions. $40 \mu \mathrm{L}$ of sample was added into 96 well-plate followed by addition of $50 \mu \mathrm{L}$ of a mixture of the RCL reagent and the substrate. The fluorescence $(360 \mathrm{~nm} / 460 \mathrm{~nm})$ change was measured by spectrophotometer (Thermo-Fisher Scientific).

\section{Isolation of DOX-loaded PEV}

$200 \mathrm{~mL}$ of PC was centrifuged at $3000 \mathrm{xg}$ for $10 \mathrm{~min}$ at $22 \pm 1{ }^{\circ} \mathrm{C}$ to obtain PLT pellet. The PLT pellet was suspended with thrombin in $200 \mathrm{~mL}$ Tyrode's buffer (final concentration, $0.1 \mathrm{U} / \mathrm{mL}$ ) to trigger activation, and incubated at $37^{\circ} \mathrm{C}$ for $30 \mathrm{~min}$. The activation was stopped by 0.5 M EDTA in Tyrode's buffer (final concentration, 20 $\mathrm{mM})$. The solution was then centrifuged at $3000 \mathrm{xg}$ for $10 \mathrm{~min}$ at $24 \pm 3^{\circ} \mathrm{C}$ to remove PLTs. The supernatant was centrifuged at $20000 \mathrm{xg}$ for $90 \mathrm{~min}$ at $18^{\circ} \mathrm{C}$, as described in a previous study [41]. The PEV pellet was re-suspended with $2 \mathrm{~mL}$ PAS and stored at $-80^{\circ} \mathrm{C}$ until use. $100 \mu \mathrm{L}$ PEV were thawed at $37^{\circ} \mathrm{C}$ then incubated with $900 \mu \mathrm{L}$ of $100 \mu \mathrm{M}$ DOX in PAS at $37^{\circ} \mathrm{C}$ for $1 \mathrm{~h}$. The solution was centrifuged at $20000 \mathrm{xg}$ for $90 \mathrm{~min}$ at $18{ }^{\circ} \mathrm{C}$. DOX-loaded PEV (PEV-DOX) pellet was resuspended with $1 \mathrm{~mL}$ of PAS for further tests.

\section{Characterization of DOX-loaded PEV}

To observe the delivery of DOX to cells by DOX-loaded PEV, $1 \times 10^{5}$ / well MCF-7 and MDA-MB-231 were seeded on coverslips in 6-well plates at $37^{\circ} \mathrm{C}$ overnight. Approximate $200 \mu \mathrm{L}$ of $1 \times 10^{8}$ DOX-loaded PEV were deposited on coverslips and maintained at $37^{\circ} \mathrm{C}$ for 30 min. The samples were then fixed with $1 \mathrm{~mL}$ of $4 \%$ PFA for 10 minutes at $24 \pm 3^{\circ} \mathrm{C}$ and washed with $1 \mathrm{~mL} 1 \mathrm{x}$ PBS three times. The samples were blocked with $200 \mu \mathrm{L}$ $1 \%$ BSA at RT for 30 min prior to incubation with 200 $\mu \mathrm{L}$ CD62P at a concentration of $1: 20$ in $1 \%$ BSA for 1 $\mathrm{h}$ to stain PEV. The coverslips were mounted onto slides with $10 \mu \mathrm{L}$ Mounting Medium with DAPI to stain nuclei and visualized 3D images by deconvolution fluorescence microscopy. $1 \mathrm{~mL}$ of isolated PEV and PEV-DOX in PAS were measured by nanoparticle tracking analysis (NTA; Nanosight NS300 system; Malvern, UK) with a 488-nm laser and CCD camera (sCMOS). Samples were processed as described above. The syringe pump speed was set to 50 . The data were analyzed three times during 60 $\mathrm{s}$ at $24 \pm 1^{\circ} \mathrm{C}$, and the videos were recorded. Data were analyzed with NTA software 3.1 as provided by the supplier (Malvern).

\section{In vitro cell proliferation and cytotoxicity assay}

$100 \mu \mathrm{L}$ of $5 \times 10^{4}$ MCF-7 and MDA-MB-231 cells $/ \mathrm{mL}$ were seeded in 96-well plates overnight and subsequently treated with DOX-loaded PLT, DOX and liposomal DOX (TTY Biopharm, Taipei, Taiwan). After $48 \mathrm{~h}$ of incubation, cell proliferation was measured with a 5-bromo-2'- 
deoxyuridine (BrdU) cell proliferation enzyme-linked immunosorbent assay (ELISA; Roche Diagnostics, Mannheim, Germany). In addition, the in vitro cytotoxicity was assessed by a Cell Counting Kit-8 (CCK-8; Sigma-Aldrich) assay. $100 \mu \mathrm{L}$ of $5 \times 10^{4}$ A549, HCT 116 and MDA-MB-231 cells $/ \mathrm{mL}$ were seeded in 96-well plates at $37 \pm 1{ }^{\circ} \mathrm{C}$ and treated with fresh and cryopreserved DOX-loaded PLT, free DOX, or liposomal DOX for $48 \mathrm{~h}$. The CCK- 8 solution was added to each well and incubated for $3 \mathrm{~h}$ at $37 \pm 1{ }^{\circ} \mathrm{C}$. Both assays of plates were read at 450 and $690 \mathrm{~nm}$ as reference wavelengths in a spectrometer. They were calculated as a percent of the control using the following formula: Cell proliferation $(\%)=$ (optical density (OD) of the experimental group / OD of the control group) $\times 100$.

\section{Statistical analysis}

All tests were done in at least three independent experiments and using different batches of fresh and cryopreserved DOX-loaded PLT to ensure reproducibility. Results are expressed as the mean \pm standard deviation (SD). The statistical analyses were performed using GraphPad Prism 6 software with a one-way ANOVA, two-way ANOVA or a paired t-test. A $p$ value $<0.05$ was considered the be significant $(* p<0.05, * * p<0.01$,

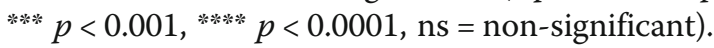

\section{Results}

\section{DOX loading procedure and characterization}

Over 50 clinical-grade human PC were produced by licensed blood collection procedures. The PC contained $1.24 \pm 0.27 \times 10^{9} \quad \mathrm{PLT} / \mathrm{mL}, \quad 1.18 \times 10^{6} \pm 1.29 \times 10^{6} / \mathrm{mL}$ white blood cells, and $8.3 \pm 8.5 \times 10^{7} / \mathrm{mL}$ red blood cells. Three to nine days after collection, PC was centrifuged at $1500 \mathrm{xg}$ for $10 \mathrm{~min}$ to isolate the PLT and remove plasma. The isolated PLT was suspended in a PAS. To prepare DOX-loaded PLT, PLT was incubated for $1 \mathrm{~h}$ at
$37 \pm 1{ }^{\circ} \mathrm{C}$ in $100 \mu \mathrm{M}$ of DOX solubilized in PAS. DOX loading within PLT by this passive transfer was demonstrated by fluorescence microscopy and 3D deconvolution microscopic images (Fig. 1a). Storing the PC for up to 9 days after collection at $22 \pm 2{ }^{\circ} \mathrm{C}$ increased the quantity of DOX loaded from $30.71 \mu \mathrm{M}$ at day 3 to $49.78 \mu \mathrm{M}$ at day 9, corresponding to 15 to $36 \times 10^{6}$ molecules of DOX per PLT (Table S1). The quantity of DOX loaded increased from day 3 to day 6 after PC collection, then reached a plateau.

Evidence of the capacity of the freshly loaded PLT to transfer DOX to cancer cells nuclei was first checked by time-lapse microscopy. DOX transfer was concomitant with binding of PLT to cancer cell membranes (Fig. 1b) and was completed as quickly as $90 \mathrm{~min}$ of incubation (Fig. S1), strongly suggesting that MCF-7 cells released factors stimulating PLT activation and DOX release. The BrdU assay to compare the in vitro cytotoxicity of DOXloaded PLT, DOX, and liposomal DOX found mean respective $50 \%$ inhibitory concentration (IC50) values (expressed in DOX equivalents) at $48 \mathrm{~h}$ of $0.14 \mu \mathrm{M}$ for free DOX and DOX-loaded PLT, and $2.31 \mu \mathrm{M}$ for liposomal DOX with MCF-7, and 0.25, 0.24, and $2.25 \mu \mathrm{M}$, respectively, with MDA-MB-231 cells (Fig. S2). Therefore, these human PLT could readily and reproducibly be loaded with DOX and the toxicity of the resulting DOX-loaded PLT formulation was similar to that of free DOX and even over 10 times stronger than that of liposomal DOX.

\section{Freezing of DOX-loaded PLT}

To facilitate clinical translation and administration schedule to patients, it is important that DOX-loaded PLT can be stored over the duration of treatment. Therefore, we evaluated the possibility to freeze and store DOX-loaded PLT at $-80{ }^{\circ} \mathrm{C}$ in the presence of $6 \%$ DMSO as it is a cryoprotectant commonly used to store stem cells in a

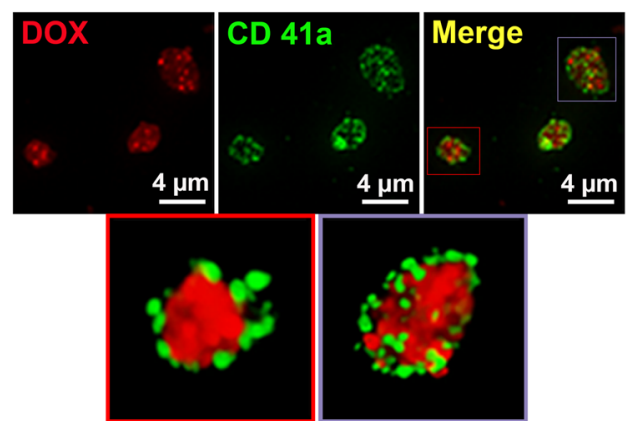

b

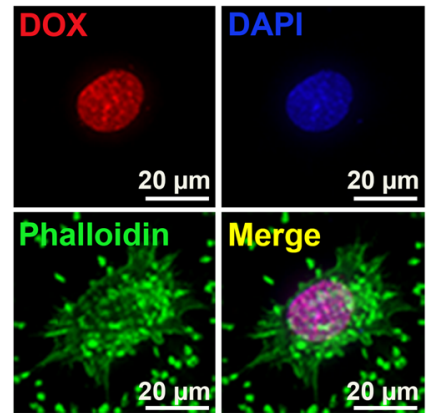

Fig. 1 Characterization of fresh DOX-loaded PLT. (a) Deconvolution fluorescence images revealed the presence of DOX (red) within fresh PLT stained with PLT membrane marker GPIlb (CD41a). (b) Deconvolution fluorescence images of MCF-7 breast cancer cells incubated with DOXloaded PLT; nuclei were stained with DAPI (blue) and actin of MCF-7 and PLT with phalloidin (green) 
similar concentrations for stem cell transplantation. Cryopreserved DOX-loaded PLT was prepared as Fig. 2a. Deconvolution microscopy demonstrated that DOX could still be visualized within PLT after the freeze and thaw cycle (Fig. 2b), and Western blot identified that the expression of functionally important PLT membrane receptors (CD41, CD61, and PAR-1) was also preserved and similar to that in fresh DOX-loaded PLT (Fig. 2c). The morphologies of fresh DOX-loaded PLT and cryopreserved DOX-loaded PLT in SEM were similar to those of PLT and cryopreserved PLT with no evidence of formation of pseudopods, a visual marker of PLT activation [42], as observed in the thrombin-treated samples (Fig. S3). The thromboelastography functional assay was then used to evaluate the hemostatic activity and contribution of PLT to the strength of fibrin clots. The reaction time ( $R$ time, Fig. 2d) for DOX-loaded PLT was $7.17 \pm 0.35 \mathrm{~min}$ and $6.47 \pm 0.42 \mathrm{~min}$ for cryopreserved DOX-loaded PLT, both significantly $(p<0.01)$ shorter than that of $8.47 \pm$
0.35 min for PLT, but not significantly different $(p>0.05)$ from one another. More importantly, maximum amplitude (MA) values of DOX-loaded PLT or cryopreserved DOX-loaded PLT, a parameter directly linked to the functional contribution of PLT to fibrin clots strength, did not significantly differ from each other $(\mathrm{p}>0.05)$ or from that of normal PLT (Fig. 2e). As expected, MA values of cryopreserved DOX-loaded PLT were significantly higher $(p<$ 0.0001) than that of PLT-poor plasma (negative control). Thus, loading of DOX in PLT and subsequent freezing and thawing did not significantly affect the hemostatic function of PLT associated with the activity of the GPIIb/ IIIa receptor, which is a key integrin in the PLT-cancer interaction loop.

Drug release of fresh and cryopreserved DOX-loaded PLT in various $\mathrm{pH}$ and cancer conditioned medium

To assess the maintenance of the bioreactivity of the membrane of the loaded PLT, we determined how $\mathrm{pH}$

\section{a}

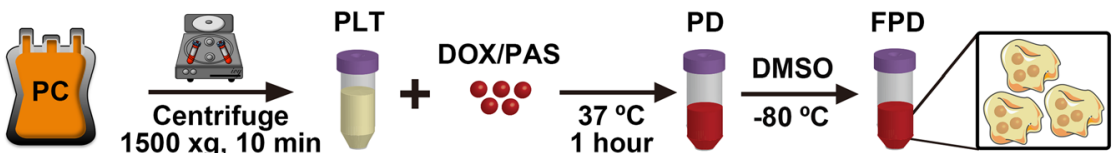

b

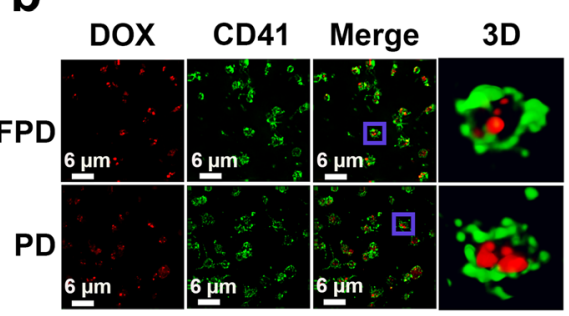

C

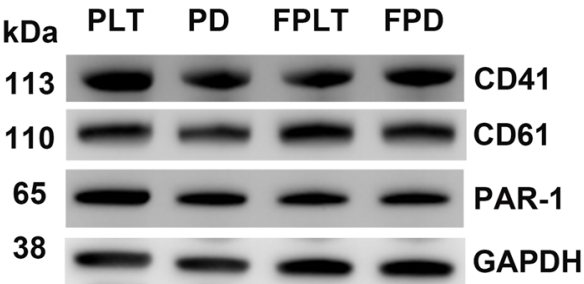

e

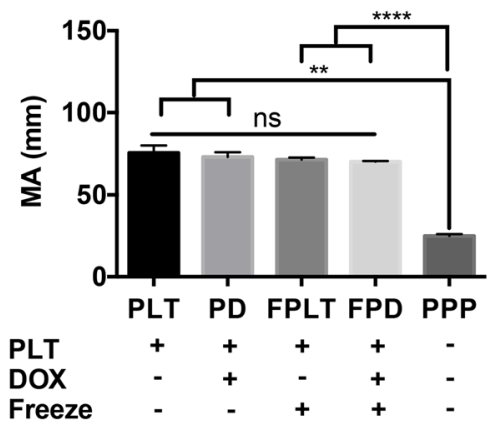

Fig. 2 Characterization of fresh and cryopreserved DOX-loaded PLT. (a) Scheme of preparation of PD and FPD. (b) Fluorescent images of FPD compared to PD. (DOX: red, PLT membrane marker: green) (c) Western blot analysis showing similar expression of membrane surface markers: CD41, CD61, and PAR-1 in PLT, DOX-loaded PLT, cryopreserved PLT and cryopreserved DOX-loaded PLT; GAPDH was used as a control. The PLT functional assay of R time (d) and MA values (e) of PLT, DOX-loaded PLT, cryopreserved PLT, cryopreserved DOX-loaded PLT, and platelet-poor plasma (PPP) determined by PLT functional thromboelastography assay. ${ }^{*} p<0.05,{ }^{* *} p<0.01,{ }^{* * *} p<0.0001$, ns $=$ non-significant. Abbreviations: PC: platelet concentrate, PLT: platelet, DOX: doxorubicin, PAS: PLT additive solution, PD: DOX-loaded PLT, FPD: cryopreserved DOX-loaded PLT 
influenced the release kinetics of DOX in vitro, as lower $\mathrm{pH}$ is a characteristic of the tumour microenvironment. DOX-loaded PLT were transferred into Eppendorf and residual DOX still present in PLT was quantified over-time (we did not use a dialysis membrane as it could cause PLT adhesion, activation and aggregation potentially resulting in artefactual drug release). The cumulative amount of DOX released by DOX-loaded PLT or cryopreserved DOX-loaded PLT in PAS or phosphate-buffered saline (PBS) gradually increased over $72 \mathrm{~h}$. It reached approximately $56 \%$ at pH 7.4 in PAS and PBS, implying that these two formulations did not impact, at least at $\mathrm{pH} 7.4$, the kinetics of DOX release, nor did the additional freezethaw process used to prepare cryopreserved DOX-loaded PLT. Approximately $21 \%$ of the initial DOX content was still present within PLT after 6 days in PAS at pH 7.4 (Fig. S4). In contrast, lower $\mathrm{pH}$ significant fastens $(p<0.0001)$ the release of DOX. The mean total percentages of DOX released from DOX-loaded PLT in PBS over $72 \mathrm{~h}$ reached approximately $56.91 \%$ at $\mathrm{pH} 7.4,74.93 \%$ at $\mathrm{pH} 6.5$, and 88.03\% at pH 5.5 (Fig. 3a). The percentages of DOX released from cryopreserved DOX-loaded PLT in PBS reached $82.60 \%$ at $\mathrm{pH} 5.5,68.57 \%$ at $\mathrm{pH} 6.5$, and $55.54 \%$ at pH 7.4 (Fig. 3b). Thus, the release of DOX by both cryopreserved DOX-loaded PLT and DOX-loaded PLT was $\mathrm{pH}$-dependent and enhanced by low $\mathrm{pH}$.

We then performed cancer cell cultures and collected the conditioned medium and checked for the presence of cancer cell-derived extracellular vesicles expressing tissue factor (TF-EV), as TF is known to be a key factor of PLT activation in cancer patients [43, 44]. The supernatant of the conditioned medium of MDA-MB-231 cancer cells (MDA-MB-231-EV) had a content of TF-EV $(468.90 \pm 54.15 \mathrm{pg} / \mathrm{mL})$ significantly higher $(p<0.0001)$ than that of its control medium (DMEM; not detectable) (Fig. S5). DOX release from DOX-loaded PLT exposed to MDA-MB-231-EV for $72 \mathrm{~h}$ was significantly $(\mathrm{p}<$ $0.0001)$ higher $(70.61 \%)$ than when they were exposed to DMEM (52.16\%) or PAS (55.22\%) (Fig. 3a). The DOX release profile from cryopreserved DOX-loaded PLT was also significantly $(p<0.001)$ higher in MDA-MB-231-EV (66.67\%) than in DMEM (55.83\%) or PAS (52.28\%) (Fig. 3d). Thus, cancer cell released TF-EV and stimulated the release of DOX from DOX-loaded PLT and cryopreserved DOX-loaded PLT. Approximately 33\% of DOX was present within PLT after $72 \mathrm{~h}$ of exposure to MDA-MB-231-EV (Fig. 3d), indicating that PLT can serve as a long-term DOX delivery system. Thus we observed an enhanced release of DOX from DOXloaded PLT by exposure to low $\mathrm{pH}$ and TF-EV, used to mimic conditions present in the tumour environment.

\section{MDA-MB-231 cell-derived TF-EV induce thrombin generation resulting in PLT activation and PEV release} MDA-MB-231 cell-derived TF-EV has been shown to activate PLT through thrombin generation in plasma

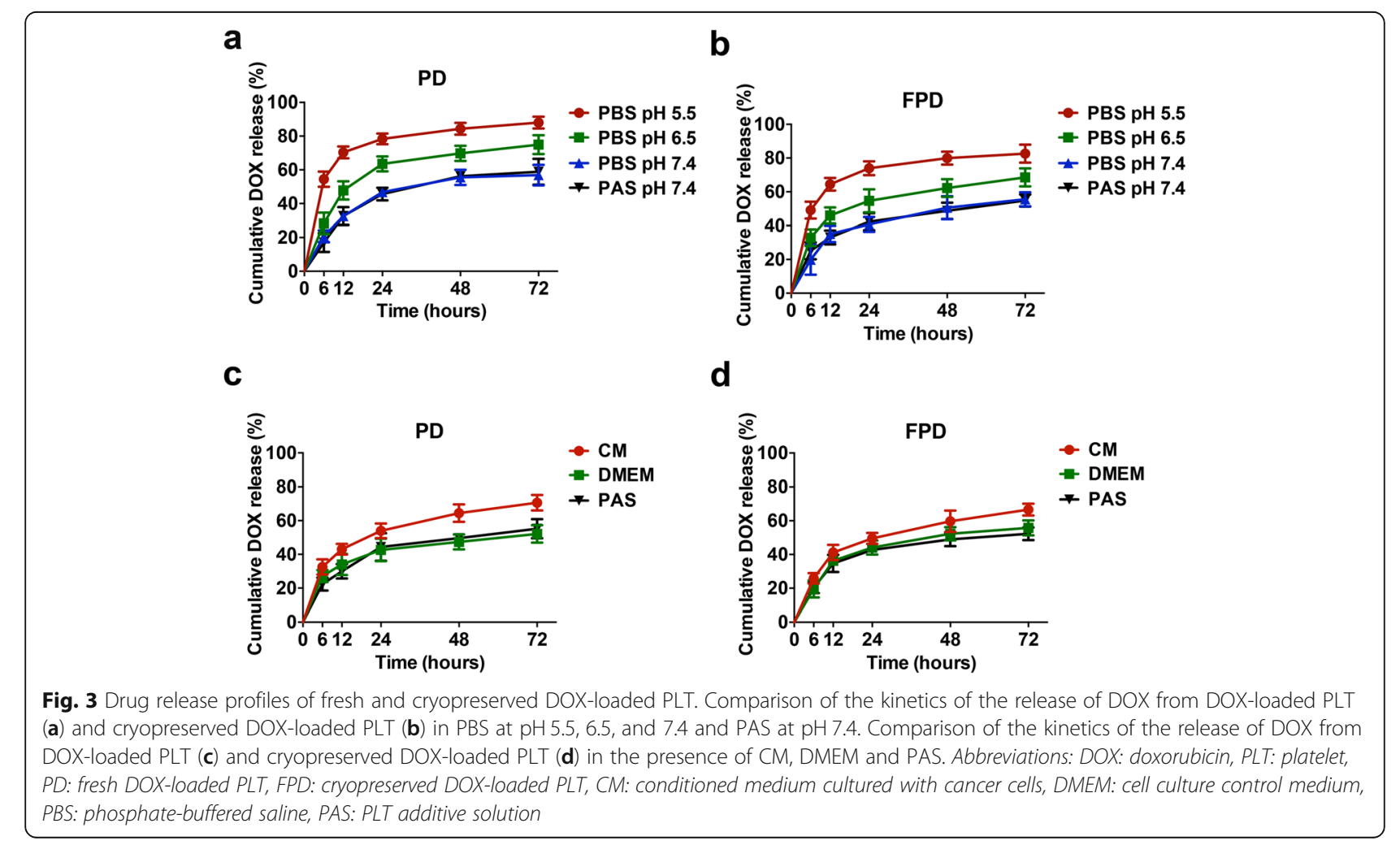


[12]. Therefore, here, MDA-MB-231 cells were incubated with cryopreserved PLT. We assessed (a) their capacity to generate TF-EV using a specific TF activity assay and (b) induce thrombin generation by a thrombin generation assay. The mean TF activity of MDA-MB-231 cells incubated with cryopreserved PLT for $1 \mathrm{~h}$ in plasma reached ca. $4800 \pm 245 \mathrm{pg} / \mathrm{mL}$, and MDA-MB-231 cells in plasma for $1 \mathrm{~h}$, was still ca. $4541 \pm 87 \mathrm{pg} / \mathrm{mL}$ (Fig. 4a). Both values were significantly higher $(p<0.0001)$ than that of cryopreserved PLT and plasma controls $(1.35 \pm 0.07$ and $1.18 \pm 0.2$ $\mathrm{pg} / \mathrm{mL}$, respectively). The MDA-MB-231-EV induced thrombin formation (Fig. 4b). The mean peak of thrombin generation was ca. $856 \pm 103 \mathrm{nM}$, significantly higher $(p<0.01)$ than that by MDA-MB-231EV not exposed to cryopreserved PLT (ca. $565 \pm 68$ $\mathrm{nM})$, and significantly higher $(\mathrm{p}<0.0001)$ than that by cryopreserved PLT alone (ca. $62 \pm 23 \mathrm{nM}$ ) and plasma (undetectable). Thus, cancer cells incubated with PLT in plasma induced TF-EV expression and thrombin generation resulting in PLT activation.

We were then interested in elucidating the contribution of PEV in the transfer of DOX to cancer cells. Both
PLT and cryopreserved DOX-loaded PLT exposed to thrombin could be activated, as evidenced in SEM by the formation of pseudopods (Fig. 4c). Thrombinactivated cryopreserved DOX-loaded PLT released PEV of approximately $100 \sim 250 \mathrm{~nm}$ as assessed by scanning electron microscopy (Fig. 4c, bottom right figure). This indicated that the surface membrane receptors on cryopreserved DOX-loaded PLT remained functional, leading to the capacity to induce PLT activation in response to thrombin agonist stimulation. Thus, to sum-up, MDA-MB-231 cells incubated with cryopreserved PLT induced the release of TF-EV and thrombin generation resulting in PLT activation and subsequent release of PEV.

\section{Isolation of DOX-loaded PEV and DOX delivery to cancer cells}

It has been shown that PEV can infiltrate solid tumours and transfer their content to cancer cells [45]. We therefore elucidated further the functional activity of DOXloaded PEV generated by thrombin activation of unloaded PLT, and examined their capacity to deliver DOX to cancer cells. PEV-DOX were compared to

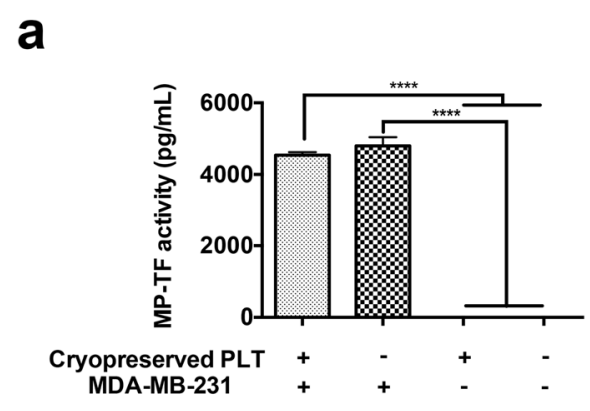

b

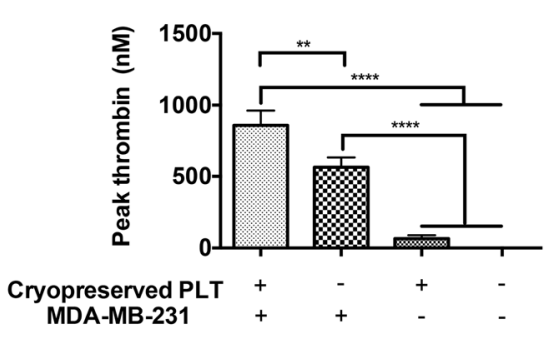

\section{C}
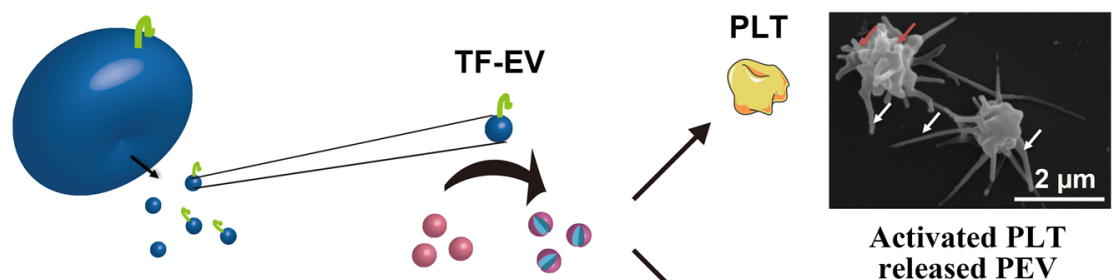

Activated PLT released PEV

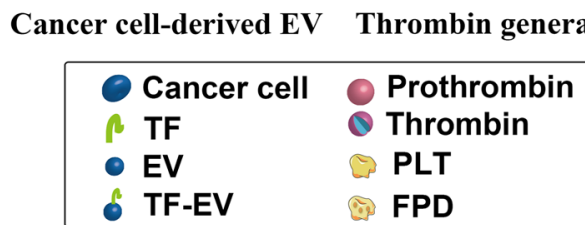

on

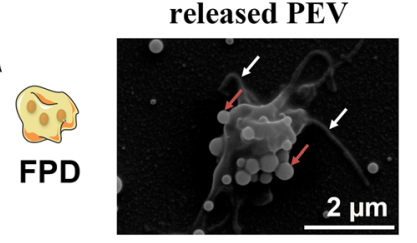

Fig. 4 MDA-MB-231 cells trigger PLT activation and thrombin generation. (a) MP-TF activity and (b) thrombin generation induced by cryopreserved PLT with MDA-MB-231 cells, MDA-MB-231 cells, cryopreserved PLT and PPP, as measured by MP-TF activity assay and thrombin generation assay, respectively. (c) Schematic representation of the mechanisms through thrombin induced activation of cryopreserved DOXloaded PLT compared to PLT to form peudopodia (white arrow) and release of PEV (red arrow). $\left({ }^{* *} p<0.01,{ }^{* * * *} p<0.0001\right.$. Abbreviations: $P C$ : platelet concentrate, PLT: platelet, DOX: doxorubicin, FPD: cryopreserved DOX-loaded PLT, PEV: PLT-derived extracellular vesicle. PPP: PLT poor plasma 


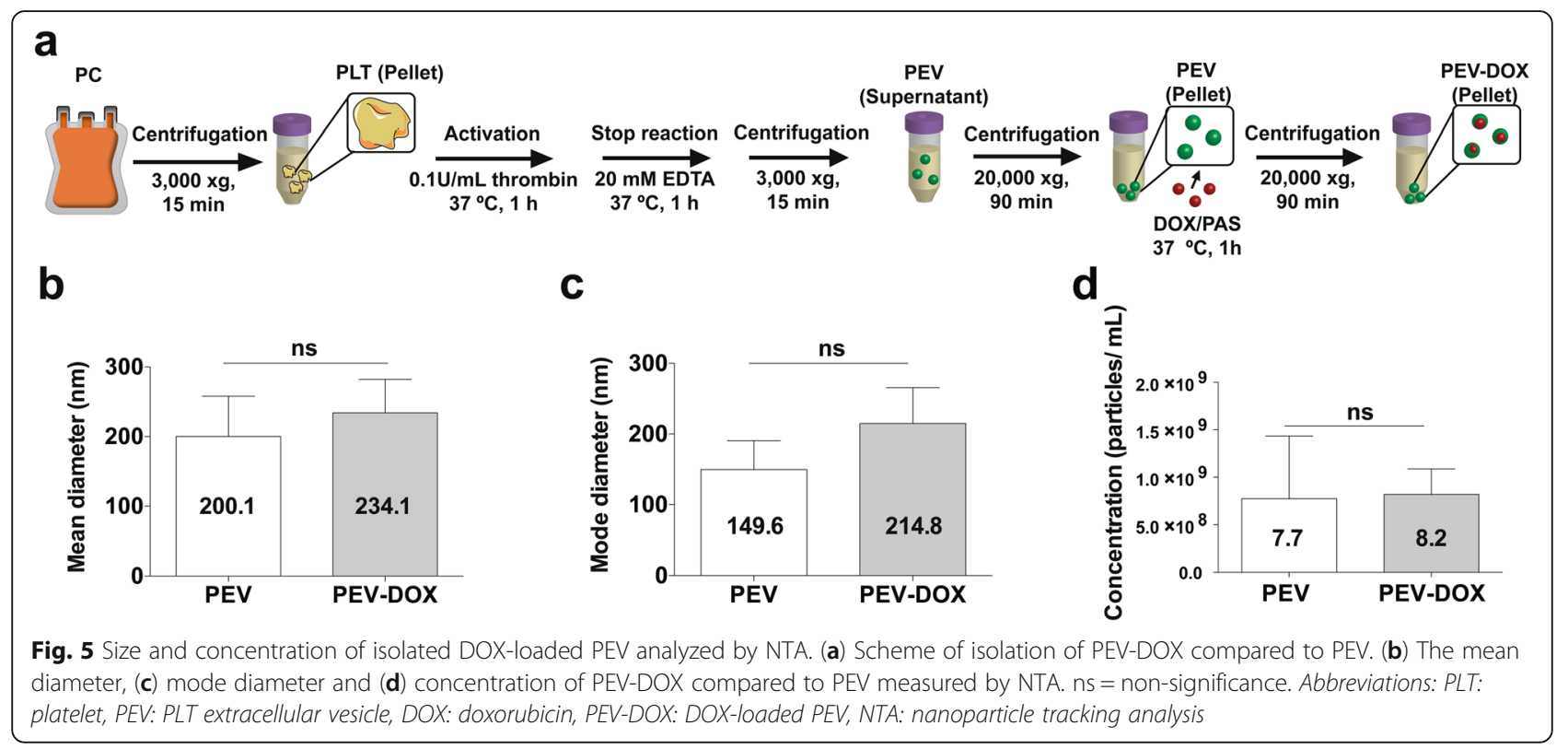

unmodified PEV (Fig. 5a). The NTA analysis showed that mean size of PEV-DOX $(234.1 \pm 48.01 \mathrm{~nm})$ was slightly larger than that of PEV $(200.1 \pm 57.71 \mathrm{~nm})$ and that DOX entrapment did not influence the physical properties of the PEV (Fig. 5b, c and d). The size distribution profiles and particle images of PEV and PEVDOX are shown in Fig. S6. When incubated with MCF-7 and MDA-MB-231, PEV-DOX transferred DOX to cancer cells nuclei within $30 \mathrm{~min}$ (Fig. 6). Therefore, these data indicated the capacity of PEV-DOX to transfer effectively DOX to cancer cells.

\section{Cytotoxic effects of fresh and cryopreserved DOX-loaded} PLT on various cancer cell lines

To verify the scientific rationale of the "Trojan Horse" PLT carrier strategy against cancer cells, and evaluate any functional impairment associated with the storage freezing, we assessed the cytotoxicity of DOX-loaded PLT and cryopreserved DOX-loaded PLT. Viabilities of the A549 lung cancer cell line, HCT 116 colon cancer cell line and MDA-MB-231 breast cancer cell line exposed to DOX-loaded PLT, cryopreserved DOX-loaded PLT, free DOX (positive control), and liposomal DOX for $48 \mathrm{~h}$ were assessed by a CCK- 8 assay. Cell medium, PLT and cryopreserved PLT used as negative controls were first confirmed to be essentially non-toxic at the doses used to three cancer cell lines. In contrast, DOXloaded PLT and cryopreserved DOX-loaded PLT $(10 \mu \mathrm{M})$ were significantly $(p \leq 0.0001)$ more toxic to both cancer cell lines than normal and cryopreserved PLT, confirming their capacity to release DOX. Cytotoxicities of DOX-loaded PLT and cryopreserved DOX-

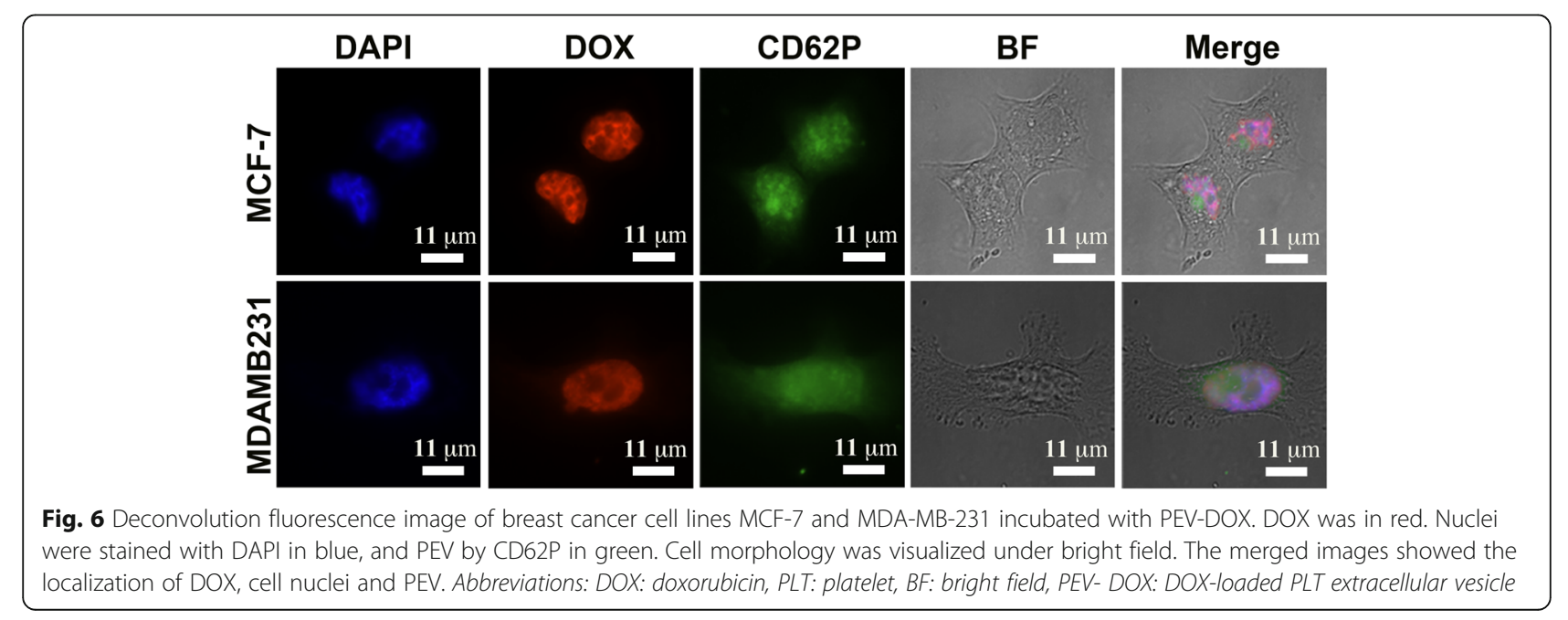


loaded PLT toward lung (Fig. 7a), colon (Fig. 7b), and breast cancer cells (Fig. 7c) were significantly less than that of DOX in the lowest range concentration, but similar at the highest concentration $(10 \mu \mathrm{M})$. Liposomal DOX exerted a highly cytotoxic effect at the highest concentration $(10 \mu \mathrm{M})$, but its effect remained limited and significantly $(p<0.0001)$ less than that of DOXloaded PLT and cryopreserved DOX-loaded PLT; this finding suggests, as expected, a lack of stimulation of DOX release from liposomal DOX under these culture conditions due to a lack of responsiveness to biological triggering factors released by cancer cells. Mean IC50 values of free DOX were $0.23,1.8$, and $0.69 \mu \mathrm{M}$ for A549, HCT 116, and MDA-MB-231 cells, respectively. Respective IC50 values of DOX-loaded PLT were 2.06, 1.94 , and $2.37 \mu \mathrm{M}$ of DOX-equivalents, for cryopreserved DOX-loaded PLT were 0.87, 1.7, and $1.52 \mu \mathrm{M}$, and for liposomal DOX were 20.09, 39.68, and $15.82 \mu \mathrm{M}$. While IC50 values for DOX-loaded PLT and cryopreserved DOX-loaded PLT were close to each other, and similar to that obtained with the equivalent amount of DOX, they were over 7 23-times lower than that achieved with liposomal DOX. Thus, these data indicated that DOXloaded PLT and cryopreserved DOX-loaded PLT have stronger capacities to release DOX to the cancer cell environment in vitro than does liposomal DOX. The cytotoxicity of loaded PLT was much higher in breast, lung, and colon cell lines than that of liposomal DOX, evidencing the superior reactivity of loaded PLT to act as an environment-responsive "Trojan Horse" DDS. The cytotoxic efficacy of DOX-loaded PLT and cryopreserved DOX-loaded PLT was similar to that of free DOX, suggesting quick release of DOX from loaded PLT in contact with cancer cells, consistent with the deconvolution microscopic observations showing DOX transfer in vitro within $90 \mathrm{~min}$ (Fig. S2). We suspect, however, that DOX-loaded PLT efficacy is actually stronger than that of free DOX as release studies showed that only about $66.67 \%$ of DOX present in cryopreserved DOX-loaded PLT was released after $72 \mathrm{~h}$ of culture in the presence of cancer cells (Fig. 3d). This suggests that loaded PLT, due to their unique reactivity in contact to cancer cells, especially through the release of PEV, could exert stronger toxicity at a dose lower than that of free DOX.

\section{Discussion}

Current therapeutic strategies of cancer rely upon combining surgery, chemotherapy, immuno and-chemotherapy, as well as radiation. Conventional chemotherapy using nucleotoxic agents is non-discriminative, and its use is associated with detrimental impacts on normal cells. Understandably, targeted DDS platforms could circumvent drawbacks of conventional therapies [46] by improving drug biodistributions, reaching tumour sites at effective concentrations, optimizing circulation halflives, or decreasing side effects with improved efficacy $[47,48]$. Liposomal DOX formulation does decrease the risks of drug resistance and helps improve drug solubility and stability, making drug formulation more straightforward [49]. Nevertheless, although cardiac toxicity is less pronounced, adverse events (skin reactions, peripheral neuropathy, and hypersensitivity reactions) are seen in $10 \% \sim 15 \%$ of patients [49]. Polyethylene glycol (PEG), used to improve the blood residence time of such nanocarriers, is not immunologically inert: many patients have preexisting anti-PEG antibodies that may decrease the drug efficacy and tolerance [50, 51]. A critical drawback of synthetic nanoformulations is the lack of targeting, as drug delivery towards and diffusion within the tumour site

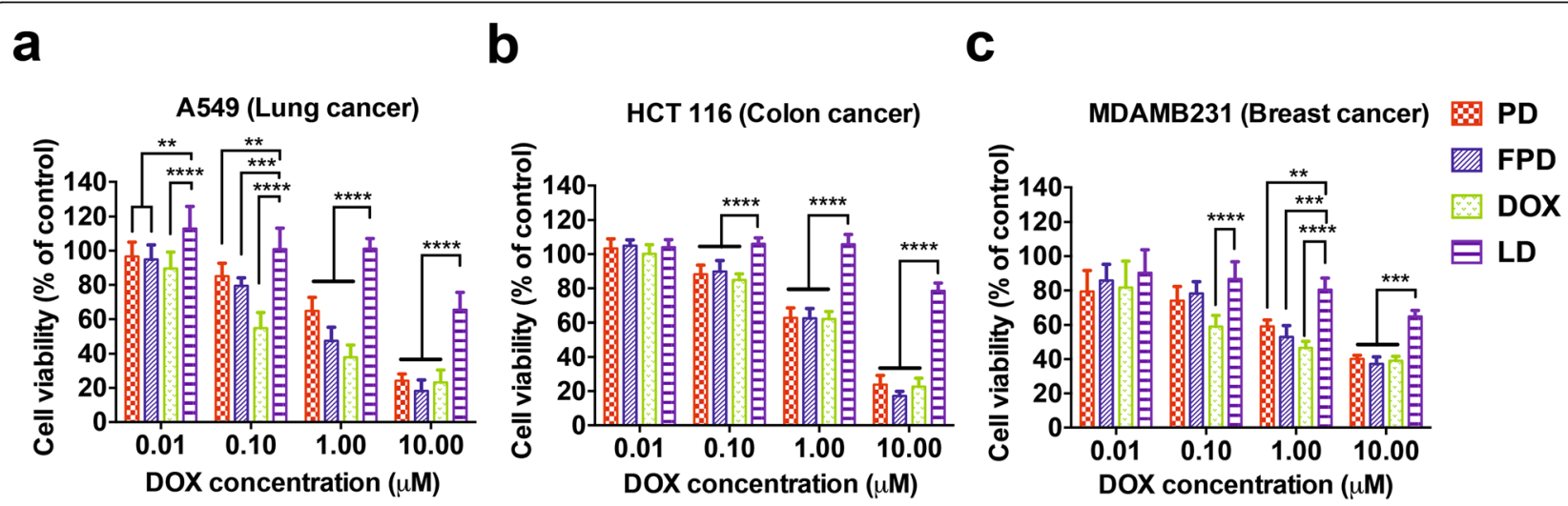

Fig. 7 In vitro cytotoxicity of fresh and cryopreserved DOX-loaded PLT on cancer cell lines. (a) A549 lung cancer cells, (b) HCT 116 colon cancer cells, (c) MDA-MB-231 breast cancer cells were grown for $48 \mathrm{~h}$ in the presence of PD, FPD, DOX and LD. The viability was assessed with a CCK-8 assay. Cytotoxicity compared to liposomal DOX. ${ }^{* *} p<0.01$, ${ }^{* * *} p<0.001,{ }^{* * * *} p<0.0001$. Abbreviations: PD: fresh DOX- loaded PLT, FPD: cryopreserved DOX-loaded PLT, DOX: doxorubicin, LD: liposomal doxorubicin 
depends only of the presumed enhanced permeability and retention effect [52]. Synthetic "undecorated" carriers are poorly equipped to overcome cellular barriers prior to releasing chemotherapeutic drugs [53], and only a mean $0.7 \%$ of drugs loaded into nanocarriers reach solid tumours [42]. Therefore, such a lack of targeting capacity explains the recent interest in using human cells as drug carriers, to take advantage of the inherent physiological targeting capacity provided by the physiological "decorations" of cell membranes by various glycoproteins [24, 30, $54,55]$. The potential to use, or mimic, circulatory cells as a DDS has been demonstrated in in vitro and in vivo models, providing a tool benefiting from the functional reactivity of cellular membranes, including PLT [23, 24, 56-58]. Circulatory cells are biocompatible and have long residence times in the blood circulation. Blood cells are sustainable cellular sources of DDS since, based on the most recent WHO survey, over 117.4 million blood collection procedures are performed each year in the world for transfusion medicine [59], providing a reliable supply. While most translational applications of blood cells have used red blood cell-based DDS so far [60], a focus on PLT has emerged recently $[24,61,62]$. PLT is a delicate cell to manipulate ex vivo as their smart lipid bilayer membrane embedded with glycoprotein integrins is highly reactive to other blood components, resulting in PLT activation, degranulation, and generation of PEV [63]. However, PLT being anucleated cells make them especially suitable for loading nucleotoxic anticancer cells agents; in addition, they expose membrane integrin receptors, such as GPIIb/ IIIa, CD62P, and protease-activated receptors [17, 64] which interact with TF-releasing tumour cells [17] and thrombin, leading to TCIPA phenomenon $[9,17,64]$ and PLT activation and degranulation. This PLT-cancer intimate connection is the very scientific rationale for using PLT as a cell-based targeted delivery platform of anticancer agents, following a "Trojan Horse" curative strategy $[24,61]$.

Our translational study is now the first to demonstrate that human PLT obtained by licensed collection procedures can be used to load DOX. We show that the resulting preparation can be stored frozen without altering the capacity to release DOX, which is essential for ease of clinical use. We documented a release mechanism of DOX based on an interaction between PLT and cancer cells involving EV and low pH. Over 50 clinicalgrade human PC were collected following licensed procedures and found to meet specifications for transfusions [65]. The PC were centrifuged to isolate the PLT and remove plasma proteins as those are known to bind DOX [66] and could have affected the DOX loading procedure. DOX loading was achieved under mild incubations $\left(1 \mathrm{~h}\right.$ at $\left.37^{\circ} \mathrm{C}\right)$, as done by others $[61,62]$, but in PAS, as this solution is licensed for transfusion in many countries $[67,68]$. PAS may decrease the risk of allergic transfusion reactions [69-71] in cancer patients eventually receiving a drug-loaded PLT-based therapy. We found that, under these conditions, the loading capacity of each PLT was as high as $15 \sim 36 \times 10^{6}$ molecules of DOX and identified that loading was at its maximal 6 days after PC collection. This high loading is over 1000fold more than in a 100-nm liposome $(10,000 \sim 15,000$ molecules/liposome) [72], thanks to PLT size and, probably, the unique capacity of entrapment of DOX through the canalicular system [73-75]. For ease of clinical treatment, it is important that the PLT formulation can undergo long-term storage. Loaded PLT could be stored frozen at $-80{ }^{\circ} \mathrm{C}$ and thawed in the presence of $6 \%$ DMSO cryoprotectant with a DOX yield of over $80 \%$. We selected DMSO as it is already approved to freeze PLT for transfusion for emergency application by the military $[34,35]$ and for supportive treatment of patients with leukemia [76]. Recent clinical studies report the safety of DMSO-cryopreserved platelet concentrates for transfusion [77]. The mild manufacturing process preserved the morphology and functionality of the DOXloaded PLT, as evidenced by (a) SEM observations, (b) maintained expression of important PLT markers by Western blotting, and (c) thromboelastography assay. In addition, the release kinetics of DOX from PLT in vitro was similar to that observed with artificial nanocarriers [78-81], and was significantly faster in acidic pH conditions mimicking the tumour microenvironment. The reasons for accelerated release of DOX by PLT at pH 5.5 is unclear and may involve several mechanisms. Acidic conditions have been shown to affect part of PLT reactivity, for instance a stronger expression of $\mathrm{P}$ selectin [82] (a protein normally present on the membrane of the alpha-granules) that may also trigger DOX release. Low $\mathrm{pH}$ is associated with a change in PLT structure [83] that may affect the "permeability" of the open canalicular system [84] and increase the discharge of DOX. Finally, a low pH typical of the tumour microenvironment can trigger the disruption of PEV-DOX, as it has been shown to occur with cancer cell-derived vesicles [85]. Interestingly, cancer cell-derived TF-EVs significantly accelerated the release of DOX by inducing PLT activation and degranulation. This is consistent with the existence of a cancer cells/PLT mutual activation loop triggered by TF released by cancer cells [11, 86]. The enhanced release of DOX from PLT by both low $\mathrm{pH}$ and TF-EV reveals a dual release mechanism of DOX from PLT carriers in conditions mimicking the tumour environment. In addition, the loaded PLT formulation was capable of reacting to thrombininduced activation and generating PEV. Such PEV, with a size close to $200 \mathrm{~nm}$, could act as an instrumental secondary DDS of DOX to cancer cells with a stronger 
capacity to infiltrate the tumour microenvironment and fuse with cancer cells [45].

The cytotoxicity of loaded PLT against cancer cell lines was much higher than that of Lipo-DOX, evidencing their superior ability to act as a "Trojan Horse" DDS. DOX-loaded PLT efficacy was similar to that of free DOX, suggesting quick release of DOX from loaded PLT in contact with tumour cells, consistent with the deconvolution microscopic observations showing DOX transfer in vitro within $90 \mathrm{~min}$ (Fig. S1). Others found superior efficacy of freshly prepared DOX-loaded PLT than free DOX in both in vitro and in vivo mice cancer models [61]. However, our data are globally consistent with the release kinetic study that showed that about $66 \%$ of the initial DOX content was released after $72 \mathrm{~h}$. This suggests that this loaded PLT formulation could exert a sustained toxicity, and at a dose lower than that of free DOX.

\section{Conclusions}

Our study supports the strong translational feasibility of using collected PLT as a smart cellular carrier of anticancer drug, and contributes to understanding the drug releasing mechanisms involved in the tumour microenvironment. Thus, as summarized and conceptualized in Fig. 8, preserved PLT membrane receptors (such as GPIIb/IIIa) serve as a targeting arm to reach tumour sites through the bloodstream, as already demonstrated in in vivo models. In the tumour microenvironment, the acidic $\mathrm{pH}$, the presence of cancer cells and TF-EV, and the thrombin-rich milieu, which is typical of all tumours, contribute to PLT activation, PEV generation, and release of DOX, in a complementary cancer cell killing loop. Our study demonstrates the role that PLT and PEV play by being a potent delivery system of DOX, and presumable other hydrophilic anti-cancer agents, in a universal "Trojan Horse" suicide strategy stimulated by cancer cells themselves. Our work further demonstrates the scientific and medical rationale of this strategy as we used clinical grade PC as starting materials, and solutions like PAS and DMSO that are already licensed for transfusion purposes to patients.

From our's and others' data [61, 62], clinical translation can be envisaged using as source material PLT collected from either cancer patients themselves or allogeneic healthy donors. PLT could be obtained using the currently licensed apheresis machines and collection procedures in a hospital setting and using PAS as PLT storage solution. DOX loading would require the development of a dedicated single-use medical device allowing aseptic addition, efficient encapsulation and subsequent washing to eliminate the free DOX, before sterile-docking addition of DMSO and freezing. Additionally, our data suggest the possibility to use DOX-loaded PEV as DDS, following the current trends seen in therapeutic applications of EVs

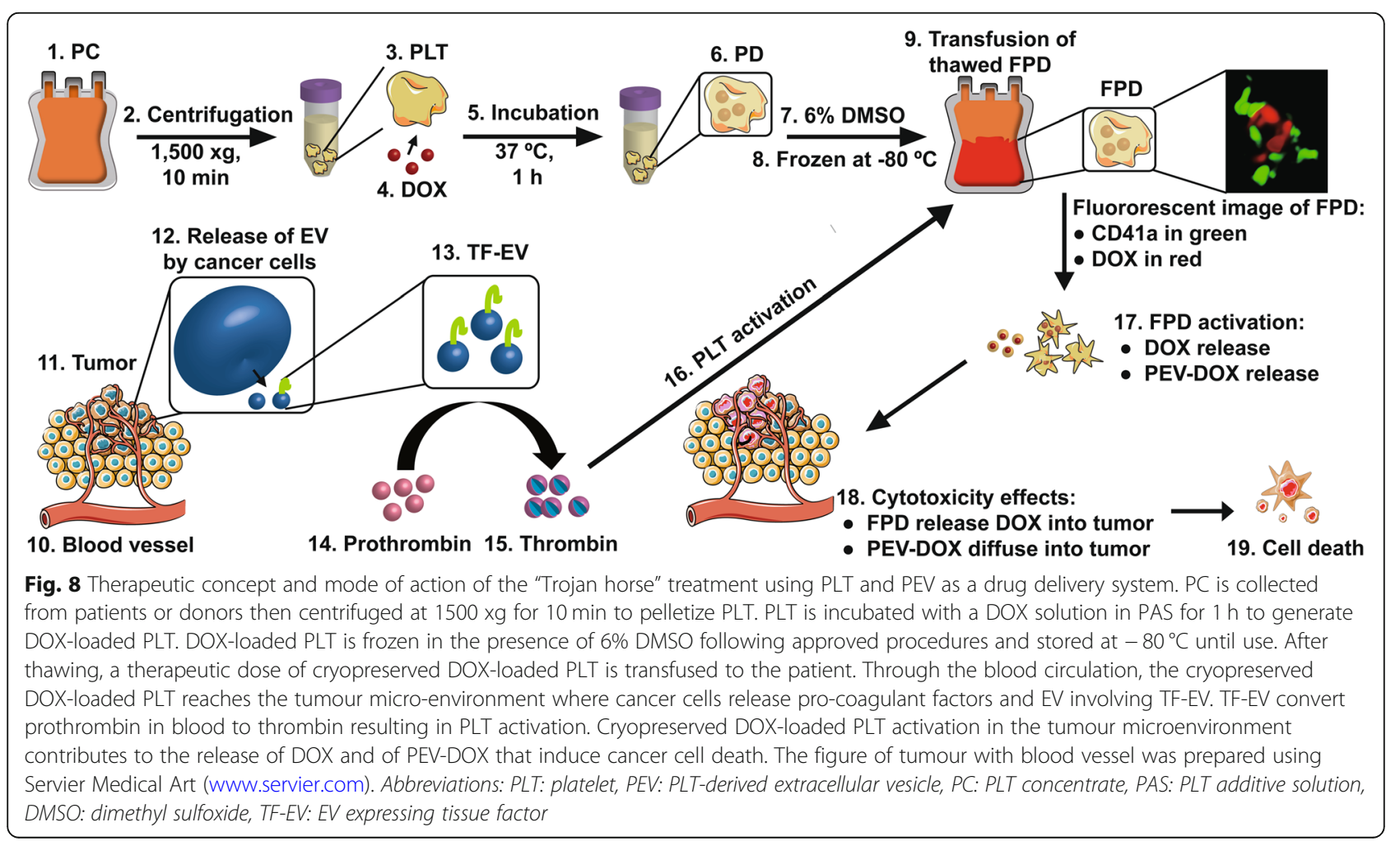


[87]. DOX-loaded PEV is a current focus of our research work that includes defining optimal loading conditions and formulation, and stability studies evaluating release profile as well as lack of aggregation and morphological changes.

\section{Supplementary information}

Supplementary information accompanies this paper at https://doi.org/10. 1186/s12929-020-00633-2.

Additional file 1: Table S1. Effects of storage conditions of $P C$ on the loading capacity of DOX into PLT.

Additional file 2: Fig. S1. Time-lapse video using deconvolution microscopy demonstrates the capacity of DOX-loaded PLT to transfer DOX to MCF-7 breast cancer-derived cells

Additional file 3: Fig. S2. Cell proliferation assay of breast cancer cells treated with fresh DOX-loaded PLT compared to other drugs.

Additional file 4: Fig. S3. Morphology of cryopreserved DOX-loaded PLT

Additional file 5: Fig. S4. The stability test of DOX-loaded PLT stored in PAS for up to 6 days.

Additional file 6: Fig.S5. MP-TF activity of conditioned medium cultured with MDA-MB-231 breast cancer cells.

Additional file 7: Fig. S6. Size distributions and images of PEV and PEV-DOX.

Additional file 8: Table S2. Western blot antibody information.

\section{Abbreviations}

BSA: Bovine serum albumin; CD41: PLT Glycoprotein Ilb; CD61: PLT Glycoprotein IIla; CD62P: P-selectin; CM: Conditioned medium; DDS: Drug delivery system; DMSO: Dimethyl sulfoxide; DOX: Doxorubicin; GAPDH: Glyceraldehyde 3-phosphate dehydrogenase; HPLC: High performance liquid chromatography; NTA: Nanoparticle tracking analysis; PAR-1: Protease activated receptor-1; PAS: Platelet additive solution; PBS: Phosphate-buffered saline; PC: Platelet concentrate; PEV: PLT-derived extracellular vesicle; PLT: Platelet; SDS: Sodium dodecyl sulfate; SEM: Scanning electron microscopy; TCIPA: Tumour cell-induced PLT aggregation; TEG: Thromboelastography; TF-EV: Extracellular vesicle expressing tissue factor

\section{Acknowledgments}

We express our thanks to Dr. Yun Yen (Taipei Medical University) for his interest and support. Technical support was provided by imaging core of core facility center at Taipei Medical University. We thank the Taipei Blood Center, Taiwan Blood Services Foundation, for the supply of the blood material.

\section{Disclosure policy}

Authors do not have any financial or other disclosures.

\section{Authors' contributions}

Conceptualization, Y.-W.W., H.G., and T.B.; methodology, Y.-W.W., C.-A.C., L.-S. L., T.B.; validation, Y-W.W., C.-C.H., C.-A.C., and T.B.; formal analysis, Y.-W.W, C.C.H., C.-A.C., and T.B.; investigation, Y.-W.W. and C.-C.H.; resources, C.-A.C. and T.B.; data curation, Y.-W.W., C.-C.H., and T.B.; Original draft preparation, W.-Y.W. and T.B.; review and editing, H.G.; visualization, Y.-W.W. and C.-A.C.; supervision, H.G. and T.B.; project administration, T.B.; funding acquisition, T.B. The authors read and approved the final manuscript.

\section{Funding}

This study was supported by the Ministry of Science and Technology (grant number 104-2314-B-038-040-MY3), the "Aim for the Top University Plan" of Taipei Medical University (TMU) and the Ministry of Education, Taiwan, and the National Health Research Institute of Taiwan (NHRI-EX109-10920EI). We express our thanks to Dr. Yun Yen at TMU, for his interest and support.

\section{Availability of data and materials}

All materials are available from the corresponding author.

Ethics approval and consent to participate

The Institutional Review Board of Taipei Medical University approved this study (TMU-JIRB no.: 201502019).

Consent for publication

Not applicable.

\section{Competing interests}

The authors declare that they have no competing interests.

\section{Author details}

${ }^{1}$ Graduate Institute of Biomedical Materials and Tissue Engineering, College of Biomedical Engineering, Taipei Medical University, 250 Wu-Xing Street Taipei 11031, Taiwan. ${ }^{2}$ Graduate Institute of Translational Medicine, College of Medicine, Taipei Medical University, Taipei, Taiwan. ${ }^{3}$ The Ph.D. Program for Cancer Biology and Drug Discovery, Center for Translational Medicine, Taipei Medical University, Taipei, Taiwan. ${ }^{4}$ International PhD Program in Biomedical Engineering, College of Biomedical Engineering, Taipei Medical University, Taipei, Taiwan. ${ }^{5}$ Department of Radiation Oncology, Taipei Medical University Hospital, Taipei, Taiwan. ${ }^{6}$ Translational Laboratory, Department of Medical Research, Taipei Medical University Hospital, Taipei, Taiwan. ${ }^{7}$ International PhD Program in Cell Therapy and Regeneration Medicine, College of Medicine, Taipei Medical University, Taipei, Taiwan. ${ }^{8}$ Saskatoon Cancer Centre and College of Medicine, University of Saskatchewan, Saskatchewan, Canada.

Received: 4 December 2019 Accepted: 19 February 2020 Published online: 23 March 2020

\section{References}

1. Burnouf T, Goubran HA, Chen TM, Ou KL, El-Ekiaby M, Radosevic M. Bloodderived biomaterials and platelet growth factors in regenerative medicine. Blood Rev, 2013:27(2):77-89.

2. Nurden AT. The biology of the platelet with special reference to inflammation, wound healing and immunity. Front Biosci (Landmark Ed). 2018;23:726-51

3. Nash G, Turner L, Scully M, Kakkar A. Platelets and cancer. Lancet Oncol. 2002;3(7):425-30.

4. Labelle M, Begum S, Hynes RO. Direct signaling between platelets and cancer cells induces an epithelial-mesenchymal-like transition and promotes metastasis. Cancer Cell. 2011;20(5):576-90

5. Li N. Platelets in cancer metastasis: to help the "villain" to do evil. Int J Cancer. 2016;138(9):2078-87.

6. Franco AT, Corken A, Ware J. Platelets at the interface of thrombosis, inflammation, and cancer. Blood. 2015;126(5):582-8.

7. Nieswandt B, Hafner M, Echtenacher B, Mannel DN. Lysis of tumor cells by natural killer cells in mice is impeded by platelets. Cancer Res. 1999;59(6): 1295-300.

8. Quail DF, Joyce JA. Microenvironmental regulation of tumor progression and metastasis. Nat Med. 2013;19(11):1423-37.

9. Goubran HA, Burnouf T, Radosevic M, El-Ekiaby M. The platelet-cancer loop. Eur J Intern Med. 2013;24(5):393-400.

10. Jurasz P, Alonso-Escolano D, Radomski MW. Platelet--cancer interactions: mechanisms and pharmacology of tumour cell-induced platelet aggregation. Br J Pharmacol. 2004;143(7):819-26.

11. Goubran HA, Stakiw J, Radosevic M, Burnouf T. Platelet-cancer interactions. Semin Thromb Hemost. 2014:40(3):296-305.

12. Gomes FG, Sandim V, Almeida VH, Rondon AMR, Succar BB, Hottz ED, et al. Breast-cancer extracellular vesicles induce platelet activation and aggregation by tissue factor-independent and -dependent mechanisms. Thromb Res. 2017;159:24-32.

13. Meikle CK, Kelly CA, Garg P, Wuescher LM, Ali RA, Worth RG. Cancer and thrombosis: the platelet perspective. Front Cell Dev Biol. 2017;4:147.

14. Donati MB. Cancer and thrombosis. Haemostasis. 1994:24(2):128-31.

15. Burnouf T, Goubran HA, Chou ML, Devos D, Radosevic M. Platelet microparticles: detection and assessment of their paradoxical functional roles in disease and regenerative medicine. Blood Rev. 2014;28(4):155-66.

16. Gay LJ, Felding-Habermann B. Contribution of platelets to tumour metastasis. Nat Rev Cancer. 2011;11(2):123-34. 
17. Goubran HA, Kotb RR, Stakiw J, Emara ME, Burnouf T. Regulation of tumor growth and metastasis: the role of tumor microenvironment. Cancer Growth Metastasis. 2014;7:9-18.

18. Janowska-Wieczorek A, Wysoczynski M, Kijowski J, Marquez-Curtis L, Machalinski B, Ratajczak J, et al. Microvesicles derived from activated platelets induce metastasis and angiogenesis in lung cancer. Int J Cancer. 2005;113(5):752-60.

19. Jing $L$, Qu H, Wu D, Zhu C, Yang Y, Jin X, et al. Platelet-camouflaged nanococktail: simultaneous inhibition of drug-resistant tumor growth and metastasis via a cancer cells and tumor vasculature dual-targeting strategy. Theranostics. 2018;8(10):2683-95.

20. Li J, Ai Y, Wang L, Bu P, Sharkey CC, Wu Q, et al. Targeted drug delivery to circulating tumor cells via platelet membrane-functionalized particles. Biomaterials. 2016;76:52-65.

21. Rao L, Bu LL, Meng QF, Cai B, Deng WW, Li A, et al. Antitumor plateletmimicking magnetic nanoparticles. Adv Funct Mater. 2017;27(9):1604774

22. $\mathrm{Xu} \mathrm{L,} \mathrm{Gao} \mathrm{F,} \mathrm{Fan} \mathrm{F,} \mathrm{Yang} \mathrm{L.} \mathrm{Platelet} \mathrm{membrane} \mathrm{coating} \mathrm{coupled} \mathrm{with} \mathrm{solar}$ irradiation endows a photodynamic nanosystem with both improved antitumor efficacy and undetectable skin damage. Biomaterials. 2018;159:59-67.

23. Agrahari $\mathrm{V}$, Agrahari $\mathrm{V}$, Mitra AK. Next generation drug delivery: circulatory cells-mediated nanotherapeutic approaches. Expert Opin Drug Deliv. 2017 14(3):285-9.

24. Burnouf T, Burnouf PA, Wu YW, Chuang EY, Lu LS, Goubran H. Circulatorycell-mediated nanotherapeutic approaches in disease targeting. Drug Discov Today. 2017;23(5):934-43.

25. Farokhzad OC. Nanotechnology: platelet mimicry. Nature. 2015;526(7571):47-8.

26. Pan V, Siva PN, Modery-Pawlowski CL, Sekhon UDS, Gupta AS. Targeted killing of metastatic cells using a platelet-inspired drug delivery system. RSC Adv. 2015;5(57):46218-28.

27. Hu CM, Fang RH, Wang KC, Luk BT, Thamphiwatana S, Dehaini D, et al. Nanoparticle biointerfacing by platelet membrane cloaking. Nature. 2015; 526(7571):118-21.

28. Hu QY, Sun WJ, Qian CG, Wang C, Bomba HN, Gu Z. Anticancer plateletmimicking nanovehicles. Adv Mater. 2015;27(44):7043-50.

29. Hu Q, Qian C, Sun W, Wang J, Chen Z, Bomba HN, et al. Engineered nanoplatelets for enhanced treatment of multiple myeloma and thrombus. Adv Mater. 2016;28(43):9573-80.

30. Wu YW, Goubran H, Seghatchian J, Burnouf T. Smart blood cell and microvesicle-based Trojan horse drug delivery: merging expertise in blood transfusion and biomedical engineering in the field of nanomedicine. Transfus Apher Sci. 2016;54(2):309-18.

31. Kunicki TJ, Furihata K, Bull B, Nugent DJ. The immunogenicity of platelet membrane glycoproteins. Transfus Med Rev. 1987;1(1):21-33.

32. Mathur A, Swamy N, Thapa S, Chakraborthy S, Jagannathan L. Adding to platelet safety and life: platelet additive solutions. Asian J Transfus Sci. 2018; 12(2):136-40.

33. Slichter SJ, Jones M, Ransom J, Gettinger I, Jones MK, Christoffel T, et al. Review of in vivo studies of dimethyl sulfoxide cryopreserved platelets. Transfus Med Rev. 2014;28(4):212-25.

34. Valeri $C$, Feingold $H$, Marchionni L. A simple method for freezing human platelets using $6 \%$ dimethylsulfoxide and storage at $-80{ }^{\circ} \mathrm{C}$. Blood. 1974; 43(1):131-6

35. Valeri CR, Ragno G, Khuri S. Freezing human platelets with 6 percent dimethyl sulfoxide with removal of the supernatant solution before freezing and storage at $-80{ }^{\circ} \mathrm{C}$ without postthaw processing. Transfusion. 2005; 45(12):1890-8.

36. Yilmaz S, Cetinkaya RA, Eker I, Unlu A, Uyanik M, Tapan S, et al. Freezing of apheresis platelet concentrates in 6\% dimethyl sulfoxide: the first preliminary study in Turkey. Turk J Haematol. 2016;33(1):28-33.

37. Johnson LN, Winter KM, Reid S, Hartkopf-Theis T, Marks DC Cryopreservation of buffy-coat-derived platelet concentrates in dimethyl sulfoxide and platelet additive solution. Cryobiology. 2011; 62(2):100-6

38. Heemskerk JW, Willems GM, Rook MB, Sage SO. Ragged spiking of free calcium in ADP-stimulated human platelets: regulation of puff-like calcium signals in vitro and ex vivo. J Physiol. 2001;535(Pt 3):625-35.

39. Bontekoe IJ, Meer PF, Korte D. Determination of thromboelastographic responsiveness in stored single-donor platelet concentrates. Transfusion. 2014;54(6):1610-8.

40. Daeihamed M, Haeri A, Dadashzadeh S. A simple and sensitive HPLC method for fluorescence quantitation of doxorubicin in micro-volume plasma: applications to pharmacokinetic studies in rats. Iran J Pharm Res. 2015;14(Suppl):33-42.

41. Laffont B, Corduan A, Ple H, Duchez AC, Cloutier N, Boilard E, et al. Activated platelets can deliver mRNA regulatory Ago2.microRNA complexes to endothelial cells via microparticles. Blood. 2013;122(2):253-61.

42. Wilhelm S, Tavares AJ, Dai Q, Ohta S, Audet J, Dvorak HF, et al. Analysis of nanoparticle delivery to tumours. Nat Rev Mater. 2016;1(5):16014.

43. Zwicker JI. Tissue factor-bearing microparticles and cancer. Semin Thromb Hemost. 2008;34(2):195-8.

44. Geddings JE, Hisada Y, Boulaftali Y, Getz TM, Whelihan M, Fuentes R, et al. Tissue factor-positive tumor microvesicles activate platelets and enhance thrombosis in mice. J Thromb Haemost. 2016;14(1):153-66.

45. Michael JV, Wurtzel JG, Mao GF, Rao AK, Kolpakov MA, Sabri A, et al. Platelet microparticles infiltrating solid tumors transfer miRNAs that suppress tumor growth. Blood. 2017;130(5):567-80

46. Wicki A, Witzigmann D, Balasubramanian V, Huwyler J. Nanomedicine in cancer therapy: challenges, opportunities, and clinical applications. J Control Release. 2015;200:138-57.

47. Iwamoto T. Clinical application of drug delivery systems in cancer chemotherapy: review of the efficacy and side effects of approved drugs. Biol Pharm Bull. 2013:36(5):715-8.

48. Jain V, Jain S, Mahajan SC. Nanomedicines based drug delivery systems for anti-cancer targeting and treatment. Curr Drug Deliv. 2015;12(2):177-91.

49. Zahedi P, Yoganathan R, Piquette-Miller M, Allen C. Recent advances in drug delivery strategies for treatment of ovarian cancer. Expert Opin Drug Deliv. 2012;9(5):567-83.

50. Garay RP, El-Gewely R, Armstrong JK, Garratty G, Richette P. Antibodies against polyethylene glycol in healthy subjects and in patients treated with PEG-conjugated agents. Expert Opin Drug Deliv. 2012;9(11):1319-23.

51. Wang $X$, Ishida T, Kiwada H. Anti-PEG IgM elicited by injection of liposomes is involved in the enhanced blood clearance of a subsequent dose of PEGylated liposomes. J Control Release. 2007;119(2):236-44.

52. Danhier F. To exploit the tumor microenvironment: since the EPR effect fails in the clinic, what is the future of nanomedicine? J Control Release. 2016; 244(Pt A):108-21.

53. Hinde E, Thammasiraphop K, Duong HT, Yeow J, Karagoz B, Boyer C, et al. Pair correlation microscopy reveals the role of nanoparticle shape in intracellular transport and site of drug release. Nat Nanotechnol. 2017;12(1):81-9.

54. Yousefpour P, Chilkoti A. Co-opting biology to deliver drugs. Biotechnol Bioeng. 2014;111(9):1699-716.

55. Batrakova EV, Gendelman HE, Kabanov AV. Cell-mediated drug delivery. Expert Opin Drug Deliv. 2011;8(4):415-33.

56. Parodi A, Molinaro R, Sushnitha M, Evangelopoulos M, Martinez JO, Arrighetti $\mathrm{N}$, et al. Bio-inspired engineering of cell- and virus-like nanoparticles for drug delivery. Biomaterials. 2017;147:155-68.

57. Wei X, Gao J, Fang RH, Luk BT, Kroll AV, Dehaini D, et al. Nanoparticles camouflaged in platelet membrane coating as an antibody decoy for the treatment of immune thrombocytopenia. Biomaterials. 2016;111:116-23.

58. Lutz H, Hu S, Dinh P-U, Cheng K. Cells and cell derivatives as drug carriers for targeted delivery. Med Drug Discov. 2020;3:100014.

59. World Health Organization. Blood safety and availability. 2019. Available from: https://www.who.int/news-room/fact-sheets/detail/blood-safety-andavailability. Accessed 15 Feb 2020.

60. Villa CH, Anselmo AC, Mitragotri S, Muzykantov V. Red blood cells: Supercarriers for drugs, biologicals, and nanoparticles and inspiration for advanced delivery systems. Adv Drug Deliv Rev. 2016;106(Pt A):88-103.

61. Sarkar S, Alam MA, Shaw J, Dasgupta AK. Drug delivery using platelet cancer cell interaction. Pharm Res. 2013;30(11):2785-94.

62. Xu P, Zuo H, Chen B, Wang R, Ahmed A, Hu Y, et al. Doxorubicin-loaded platelets as a smart drug delivery system: an improved therapy for lymphoma. Sci Rep. 2017;7:42632.

63. Seghatchian J, Krailadsiri P. The platelet storage lesion. Transfus Med Rev. 1997;11(2):130-44.

64. Menter DG, Tucker SC, Kopetz S, Sood AK, Crissman JD, Honn KV. Platelets and cancer: a casual or causal relationship: revisited. Cancer Metastasis Rev. 2014:33(1):231-69.

65. European Directorate for the Quality of Medicines \& HealthCare. Good practice guidelines for blood establishments and hospital blood banks required to comply with EU Directive 2005/62/EC. 2013. Available from: https://www.edqm.eu/sites/default/files/medias/fichiers/good_practice_ guidelines_dec_2013.pdf. Accessed Feb 15, 2020. 
66. Chassany O, Urien S, Claudepierre P, Bastian G, Tillement J-P. Comparative serum protein binding of anthracycline derivatives. Cancer Chemother Pharmacol. 1996;38(6):571-3.

67. Slichter SJ, Corson J, Jones MK, Christoffel T, Pellham E, Bailey SL, et al. Exploratory studies of extended storage of apheresis platelets in a platelet additive solution (PAS). Blood. 2014;123(2):271-80.

68. Hornsey VS, McColl K, Drummond O, McMillan L, Morrison A, Morrison L, et al. Extended storage of platelets in SSP platelet additive solution. Vox Sang. 2006;91(1):41-6.

69. Tobian AA, Fuller AK, Uglik K, Tisch DJ, Borge PD, Benjamin RJ, et al. The impact of platelet additive solution apheresis platelets on allergic transfusion reactions and corrected count increment (CME). Transfusion. 2014;54(6):1523-9.

70. Kerkhoffs JL, Eikenboom JC, Schipperus MS, van Wordragen-Vlaswinkel RJ, Brand R, Harvey MS, et al. A multicenter randomized study of the efficacy of transfusions with platelets stored in platelet additive solution II versus plasma. Blood. 2006;108(9):3210-5.

71. Van der Meer PF. PAS or plasma for storage of platelets? A concise review. Transfus Med. 2016;26(5):339-42.

72. Olusanya TOB, Haj Ahmad RR, Ibegbu DM, Smith JR, Elkordy AA. Liposomal drug delivery systems and anticancer drugs. Molecules. 2018;23(4):907.

73. Escolar G, Leistikow E, White JG. The fate of the open canalicular system in surface and suspension-activated platelets. Blood. 1989;74(6):1983-8.

74. Escolar G, Lopez-Vilchez I, Diaz-Ricart M, White JG, Galan AM. Internalization of tissue factor by platelets. Thromb Res. 2008;122(Suppl 1):S37-41.

75. Lopez-Vilchez I, Diaz-Ricart M, Galan AM, Roque M, Caballo C, Molina P, et al. Internalization of tissue factor-rich microvesicles by platelets occurs independently of GPIIb-IIla, and involves CD36 receptor, serotonin transporter and cytoskeletal assembly. J Cell Biochem. 2016;117(2):448-57.

76. Schiffer C, Buchholz D, Aisner J, Wolff J, Wiernik P. Frozen autologous platelets in the supportive care of patients with leukemia. Transfusion. 1976; 16(4):321-9.

77. Reade MC, Marks DC, Bellomo R, Deans R, Faulke DJ, Fraser JF, et al. A randomized, controlled pilot clinical trial of cryopreserved platelets for perioperative surgical bleeding: the CLIP-I trial (editorial, p. 2759). Transfusion. 2019:59(9):2794-804

78. Charrois GJ, Allen TM. Drug release rate influences the pharmacokinetics, biodistribution, therapeutic activity, and toxicity of pegylated liposomal doxorubicin formulations in murine breast cancer. Biochim Biophys Acta. 2004;1663(1-2):167-77.

79. Gabizon A, Catane R, Uziely B, Kaufman B, Safra T, Cohen R, et al. Prolonged circulation time and enhanced accumulation in malignant exudates of doxorubicin encapsulated in polyethylene-glycol coated liposomes. Cancer Res. 1994:54(4):987-92

80. Amoozgar Z, Wang L, Brandstoetter T, Wallis SS, Wilson EM, Goldberg MS. Dual-layer surface coating of PLGA-based nanoparticles provides slowrelease drug delivery to achieve metronomic therapy in a paclitaxelresistant murine ovarian cancer model. Biomacromolecules. 2014;15(11): 4187-94.

81. Thauvin C, Schwarz B, Delie F, Allemann E. Functionalized PLA polymers to control loading and/or release properties of drug-loaded nanoparticles. Int J Pharm. 2018;548(2):771-7.

82. Etulain J, Negrotto S, Carestia A, Pozner RG, Romaniuk MA, D'Atri LP, et al. Acidosis downregulates platelet haemostatic functions and promotes neutrophil proinflammatory responses mediated by platelets. Thromb Haemost. 2012;107(1):99-110.

83. Djaldetti $\mathrm{M}$, Fishman $\mathrm{P}$, Bessler $\mathrm{H}$, Chaimoff $\mathrm{C}$. pH-induced platelet ultrastructural alterations. A possible mechanism for impaired platelet aggregation. Arch Surg. 1979;114(6):707-10.

84. Escolar G, White JG. The platelet open canalicular system: a final common pathway. Blood Cells. 1991;17(3):467-85.

85. Taraboletti G, D'Ascenzo S, Giusti I, Marchetti D, Borsotti P, Millimaggi D, et al. Bioavailability of VEGF in tumor-shed vesicles depends on vesicle burst induced by acidic pH. Neoplasia. 2006;8(2):96-103.

86. Rickles FR, Patierno S, Fernandez PM. Tissue factor, thrombin, and cancer. Chest. 2003;124(3):58S-68S.

87. Agrahari V, Agrahari V, Burnouf P-A, Chew CH, Burnouf T. Extracellular microvesicles as new industrial therapeutic frontiers. Trends Biotechnol. 2019;37(7):707-29.

\section{Publisher's Note}

Springer Nature remains neutral with regard to jurisdictional claims in published maps and institutional affiliations.

\section{Ready to submit your research? Choose BMC and benefit from:}

- fast, convenient online submission

- thorough peer review by experienced researchers in your field

- rapid publication on acceptance

- support for research data, including large and complex data types

- gold Open Access which fosters wider collaboration and increased citations

- maximum visibility for your research: over $100 \mathrm{M}$ website views per year

At BMC, research is always in progress.

Learn more biomedcentral.com/submissions 